\title{
Board-level Employee Representation (BLER) and Firms' Responses to Crisis
}

\author{
Gregoric, Aleksandra; Rapp, Marc Steffen
}

\author{
Document Version \\ Published in: \\ Industrial Relations \\ DOI: \\ 10.1111/irel.12241 \\ Publication date: \\ 2019 \\ License \\ Unspecified
}

Accepted author manuscript

Citation for published version (APA):

Gregoric, A., \& Rapp, M. S. (2019). Board-level Employee Representation (BLER) and Firms' Responses to Crisis. Industrial Relations, 58(3), 376-422. https://doi.org/10.1111/irel.12241

Link to publication in CBS Research Portal

\section{General rights}

Copyright and moral rights for the publications made accessible in the public portal are retained by the authors and/or other copyright owners and it is a condition of accessing publications that users recognise and abide by the legal requirements associated with these rights.

\section{Take down policy}

If you believe that this document breaches copyright please contact us (research.lib@cbs.dk) providing details, and we will remove access to the work immediately and investigate your claim.

Download date: 26. Apr. 2023

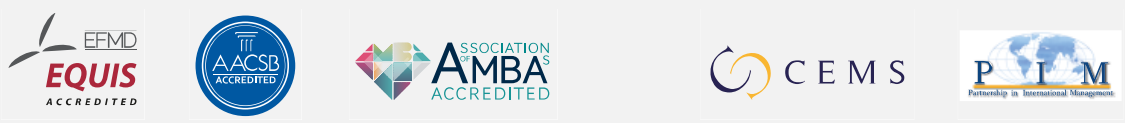




\section{Board-level Employee Representation (BLER) and Firms' Responses to Crisis}

\section{Aleksandra Gregoric and Marc Steffen Rapp}

Journal article (Accepted manuscript*)

\section{Please cite this article as:}

Gregoric, A., \& Rapp, M. S. (2019). Board-level Employee Representation (BLER) and Firms' Responses to Crisis. Industrial Relations, 58(3), 376-422. https://doi.org/10.1111/irel.12241

This is the peer reviewed version of the article, which has been published in final form at DOI: https://doi.org/10.1111/irel.12241

This article may be used for non-commercial purposes in accordance with Wiley Terms and Conditions for Self-Archiving

* This version of the article has been accepted for publication and undergone full peer review but has not been through the copyediting, typesetting, pagination and proofreading process, which may lead to differences between this version and the publisher's final version AKA Version of Record. 


\title{
Board-level Employee Representation (BLER) and Firms'
}

\author{
Responses to Crisis ${ }^{\#}$
}

\author{
Aleksandra Gregorič ${ }^{\mathrm{a}}$ \\ Marc Steffen Rapp ${ }^{\text {b,c }}$
}

Short: We hypothesize that companies with board-level employee representation (BLER) experience a lower probability of crisis-induced dismissals than other firms. Theoretically, we link this effect to the employee directors' ability to reduce the information asymmetry and moral hazard in employee-employer contracting, thereby facilitating the implementation of labor-cost adjustments that are an alternative to workforce dismissals. We confirm our hypotheses by analyzing the behavior of Scandinavian public corporations with/without employee directors during the Great Recession.

Long: We hypothesize that companies with board level employee representation (BLER) are less likely than other firms to experience crisis-induced employment reductions, since the employers and employees in BLER firms are better able to negotiate alternative labor-cost savings to preserve employment. Theoretically, we link this ability to BLER's contribution in reducing information asymmetries and moral hazard in employee-employer contracting. We confirm our hypotheses by studying Scandinavian corporations with/without BLER during the Great Recession. In line with the hypothesized cooperative nature of employee-employer agreements, we also show that BLER firms did not underperform compared to other firms during the last crisis.

JEL-Classification: L00, G3, J53

Keywords: Industrial relations, board of directors, employee directors, employment, labor costs, Great Recession

\footnotetext{
\# We would like to thank Ruth Aguilera, Morten Bennedsen, Ruediger Fahlenbrach, Marc Goergen, Takao Kato, Colin Mayer, and the seminar participants at Universita Autonoma de Barcelona, Brunel University, Gothenburg University, Utrecht University, Marburg Research Day, ASSA meeting (Chicago), IAFEP Conference (Montevideo) and the Midwest Finance Association Meeting (Chicago) for valuable comments and suggestions on this and earlier drafts of the paper. We are particularly indebted to Evis Sinani for her help on the earlier versions of this paper.
}

${ }^{a}$ Corresponding author. Department of Strategy and Innovation, Copenhagen Business School, Kilevej 14A, DK-2000, Frederiksberg (Denmark).

${ }^{\mathrm{b}}$ School of Business and Economics, Philipps-Universität Marburg, Germany.

${ }^{\mathrm{c}}$ Center for Corporate Governance, HHL Leipzig Graduate School of Management, Germany.

Aleksandra Gregorič (Email: ag.si@cbs.dk).

Marc Steffen Rapp (Email: msr@m-s-rapp.de). 


\section{Board-level Employee Representation (BLER) and Firms' \\ Responses to Crisis}

We hypothesize that companies with board-level employee representation (BLER) experience a lower probability of crisis-induced dismissals than other firms. Theoretically, we link this effect to the employee directors' ability to reduce the information asymmetry and moral hazard in employee-employer contracting, thereby facilitating the implementation of labor-cost adjustments that are an alternative to workforce dismissals. We confirm our hypotheses by analyzing the behavior of Scandinavian public corporations with/without employee directors during the Great Recession.

JEL-Classification: L00, G3, J53

Keywords: Industrial relations, board of directors, employee directors, employment, labor costs, Great Recession 
“...[t]he importance of the ability of employers and employees to tackle shifting economic conditions was amply demonstrated during the crisis when many employers worked with employees and their representatives, in particular at the company level, to help keep companies afloat, reducing the need for job losses and helping to retain key skills through, for instance, short-time working" (CEEMET, 2012, p. 3).

\section{$1 \quad$ Introduction}

The economic consequences of employee participation in corporate decision-making, particularly in the form of workers' representation on the board of directors (board-level employee representation - BLER), have been given quite some attention in the academic literature (e.g., Addison and Schnabel, 2011; Fauver and Fuerst, 2006; Gorton and Schmid, 2004; Jones, 1987; Svejnar, 1981). More recently, the public and academic debate about this characteristic of the employee-employer relationship has been gaining new momentum, with anecdotal evidence pointing to the relevance of employee-employer cooperation for swift adjustment to unfavorable economic conditions during the Great Recession (CEEMET 2012; Glassner et al., 2011; Svalund et al., 2013). ${ }^{1}$ This paper aims to contribute to this debate by analyzing the association between board-level employee representation (BLER) and firms' behavior in the event of a negative demand shock. Specifically, we discuss theoretically and analyze empirically whether employee representatives on the board of directors facilitated cooperative firm-level labor costs' adjustments during the Great Recession. ${ }^{2}$

Across Europe, many companies presumably responded to Great Recession by undertaking actions to reduce labor costs, from dismissals and early retirements to more integrative solutions based on employee-employer agreements on internal redeployments, temporary working adjustments and changes in pay systems (Glassner et al., 2011; Svalund et al., 2013). Theoretically, when workers care about both wages and employment, as is likely the case during an industry-wide shock or global crisis, integrative solutions, which allow workers to trade a (temporary) reduction in their earnings for employment, might be Pareto superior to unilateral employment reductions (Aoki, 1984; McDonald and Solow, 1981). Bargaining over integrative (cooperative) agreements is, however, subject to information asymmetries and moral hazard problems (Aidt and Tzannatos, 2002). The negotiation and implementation of such agreements might be therefore conditional on the existence of mechanisms that facilitate 
the exchange of information between the parties, provide credibility for the information exchanged and ensure an ex-post commitment to the negotiated outcome (Freeman and Lazear, 1995).

Employee representatives on the board of directors might constitute such a mechanism (Aoki, 1984; Freeman and Lazear, 1995; Kochan and Osterman, 1994). Given that they are elected by the employees and, as board members, also accountable to the firm, these directors should be able to credibly transfer information on the preferences of both employees and employers ${ }^{3}$, thereby facilitating the information exchange necessary for integrative solutions (Aoki, 1984; Freeman and Lazear, 1995). Moreover, when employees participate in the design of the firm's policy, through their representatives on the board, they will less likely renege on the reached agreements ex-post by, for example, adjusting their effort downward (McCain, 1980; Mizrahi, 2002). Upon these arguments, we in this paper propose that companies with employee representatives on their boards (BLER firms) should be better able than other firms to negotiate alternative ways of reducing labor costs, such as temporary furloughs, work sharing, bonus restructuring, and consequently less likely to reduce employment in the case of poor performance. We test this hypothesis using a sample of 365 publicly listed non-financial firms from Denmark, Sweden and Norway (Scandinavian countries) during the Great Recession.

The Scandinavian setting is well suited to this study. First, workers in Scandinavian firms employing at least (about) 30 employees have the possibility but not an obligation to establish BLER. That is, employee directors are today present only on the boards of companies whose employees or their representative unions, at some point in the past, exercised their codetermination rights and demanded the implementation of BLER. Consequently, employee directors are found in about half of the non-financial publicly listed firms in our sample; the fact that BLER is not implemented in all public corporations allows us to draw inferences on the differences between the behavior of BLER firms and comparable public corporations without employee directors. Moreover, the BLER rights have been in place since the seventies; accordingly, the BLER statuses of our sample firms have not changed since before the period of our analysis, which mitigates reverse-causality concerns in our study. Second, as did many other European firms (Gross and Acidi, 2010; European Commission, 2009), Scandinavian companies faced a substantial drop in consumer demand during the Great Recession. In Sweden and Denmark, for instance, the demand for manufacturing fell by 20 percent during 2008-2009, on average, demanding substantial 
and swift reductions in labor costs (Svalund et al., 2013). Scandinavian companies presumably responded with a variety of measures, from workforce cuts to novel integrative solutions (Svalund et al., 2013). Although, theoretically, the negotiation of the latter might be less feasible in systems with collective bargaining (Aidt and Tzannatos, 2002), such as Scandinavian countries, the local actors reportedly operated with substantial leeway to arrive at the most efficient solutions (Svalund et al., 2013). Allegedly, while national institutions and collective agreements shaped the repertoire of possible measures of burden sharing, company-level negotiations represented the key arena for bargaining over the crisis adjustments, thereby requiring extensive cooperation between the employers and the employees (Glassner et al., 2011; Svalund et al., 2013).

Previewing the results of our empirical analysis, we find that firms with board-level employee representation (BLER) were significantly less likely to enact crisis-induced employment reductions during the Great Recession. More precisely, we document that, in the wake of performance shocks during the crisis, the reductions in employment were significantly less related to firm performance in BLER firms than was the case in firms without BLER. Indeed, our data suggest that during the crisis firm performance had no impact on employment reductions in BLER firms, while lower performance in non-BLER firms associated with significant reductions in employment. Our results also suggest that the preservation of employment in BLER firms during crisis was at least in part possible due to the implementation of alternative cost-saving measures, resulting in a decrease in labor costs per employee. In line with the hypothesized cooperative nature of these agreements, we observe that, in terms of shareholder value, BLER firms performed no worse compared to non-BLER firms during crisis. These results sustain our theoretical propositions on the relevance of board-level employee representation (BLER) for the implementation of cooperative firm-level responses to crisis.

Although the outlined empirical results are based on firm-fixed effects or first-difference estimators, and are in line with the theoretical arguments and anecdotal evidence offered in the literature, our research design does not allow for perfect identification of the BLER effects. The BLER status is, by the definition of the law, an endogenous choice of the employees, meaning that — although introduced way before the crisis — our BLER variable might be capturing some unobservable firm characteristics. We mitigate this issue in a number of ways. First, we inspect the differences in the observable characteristics of firms with and without employee directors and, 
subsequently, include a number of firm-specific covariates in all our regressions. We find that the BLER status is positively associated with firms' age and size, but also with headquarter location, sector affiliation and the type of firms' business model. Second, we measure employee board representation as of the year 2007; since the crisis was unexpected, using a pre-crisis year to measure BLER should reduce reverse-causality issues. ${ }^{4}$ Third, we separate the effect of employee board representation (BLER) from a battery of other characteristics that could potentially drive our results (firm size, regional characteristics, family control and union density) by including additional interaction terms in our main regressions. Fourth, we corroborate our results by implementing a number of robustness checks, such as using alternative definitions of the dependent variable and firm performance, and propensity score matching. Finally, we provide substantial theoretical, institutional and secondary case evidence in support of the fact that mechanisms facilitating company-level cooperation between the employers and employees, such as BLER, were crucial to the achievement of integrative company-level solutions during the Great Recession, and that such solutions were made possible and even facilitated by the Scandinavian collective bargaining systems (Svalund et al., 2013; Andersen et al., 2014). The case-based evidence also indicates that the implementation of such solutions was somewhat easier in the firms with long traditions of company-level negotiations and with workers' representation within the top organizational layers (Svalund et al., 2013; Glassner et al., 2011).

Our study makes two key contributions to the literature. First, we complement the empirical literature on the economic consequences of BLER, by providing novel evidence to the fact that the joint involvement of employees and employers in formulating strategic responses might lead to cooperative outcomes during crises. With this, we provide new evidence in support of employee board representation, thereby advancing the stream of research that regards board-level employee representation and other forms of workers' participation in the firms' decision-making as an efficient way to manage labor relations, reduce shareholder-labor conflict and facilitate efficient adjustments to economic shocks (Strauss and Rosenstein, 1970; Aoki, 1984; Freeman and Lazear, 1995). Second, by corroborating previous notions of how employee board participation shapes labor-cost-related policies during crises, our study contributes to the scholarly work shedding light on the role of governance characteristics in shaping firms' adaptation to the Great Recession and other environmental changes (e.g., Lins et al., 2013; Svalund et al., 2013; Frank, 2014). Our findings suggest that other governance characteristics, such as the presence 
of family owners with significant share of voting rights, were not equally beneficial with regards to employment security during the Great Recession, thereby suggesting that cooperative solutions in the sense of Aoki (1984), gained through formal involvement of employees in firms' strategic decisions, cannot be entirely replicated by other governance mechanisms.

\section{$2 \quad$ Theoretical Framework}

For most firms, labor is a fundamental ingredient of the production process and simultaneously an important cost driver. ${ }^{5}$ Accordingly, a negative shock in the product market will undoubtedly require some adjustment in terms of labor costs. While a static view might suggest that the best strategy is to simply reduce employment, a more dynamic perspective acknowledging that labor costs are characterized along two dimensions, i.e., level of employment and wages, suggests a more balanced view, in which the employment and wages are adjusted simultaneously. To see this, consider the static model of a firm with a fixed production technology that translates labor $L$ into profit $\pi$ as follows:

$$
\pi(L)=R(L)-w L
$$

where $R(\cdot)$ is a concave function of operating profit before labor costs and $w L$ denotes the direct labor costs that are, by assumption, a function of employment $L$ and the wages $w$ paid to the employees. For simplicity, we assume that employees are homogeneous and we ignore taxes here. The employer (firm management) is assumed to be interested in the optimal, i.e., profit-maximizing, size of the firm's operations, resulting in the optimal level of employment, $L^{*}$. Examining the first-order condition for Eq. (1), we see that the optimal firm size is a function of the market demand for goods or services produced by the firm, as represented by $R^{\prime}(\cdot)$, and the level of wages the firm pays to its employees, $w$. Assuming that employers take the wages as given, Panel A of Figure 1 illustrates the resulting labor demand function of the firm, which is decreasing in the wage level $w$.

\section{Figure1: Illustrating labor demand functions}



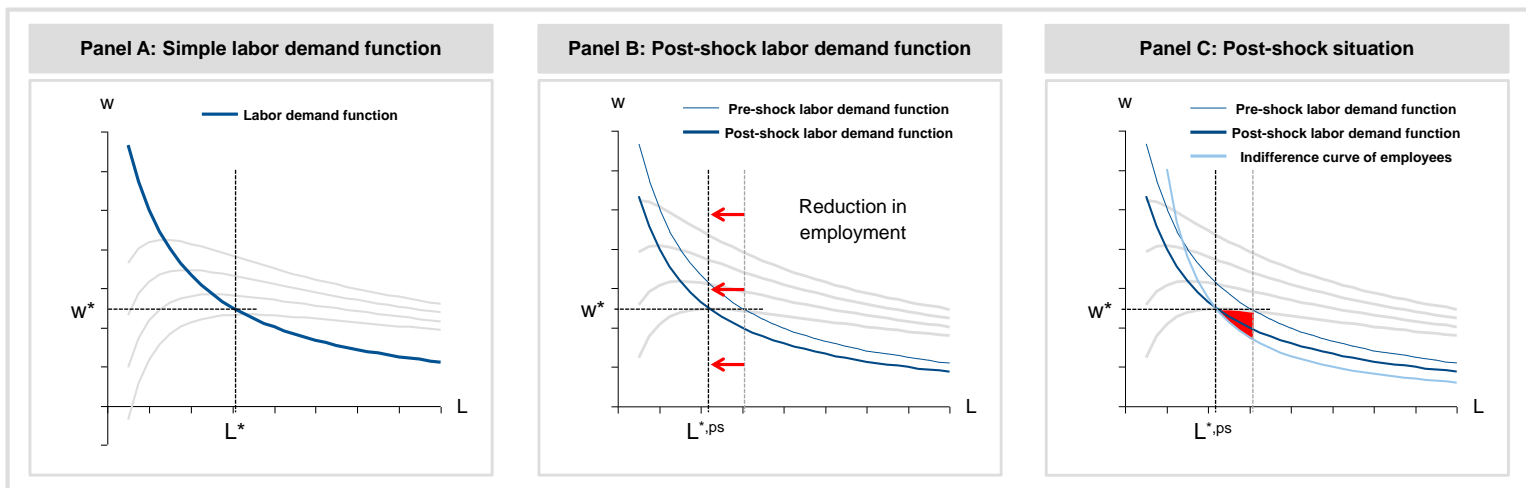

Notes: This figure illustrates labor demand functions and crisis responses in our model. While Panel A illustrates the labor demand function in an undistorted equilibrium situation (pre-crisis), Panel B illustrates the post-shock labor demand function (assuming employment reduction to be the only available response path) and Panel C illustrates the potential improvement to be gained from more general crisis responses. 
Now assume the firm faces a negative shock in the product market. Technically, the function $R(\cdot)$ shifts to the Southwest. Thus, the optimizing employer will have to adjust the firm size and thus the labor costs. An employer who takes the wages as fixed will react by reducing employment $L$ to a lower level, as shown in Panel B of Figure 1. Such a solution may, however, be less beneficial for the firm under a dynamic view, as it may result in higher hiring costs in the future, once the product market demand recovers (Glassner et al., 2011). Simultaneously, such a solution is suboptimal from the perspective of the employees. Arguably, workers care about both employment and the wage level, particularly in the case of high employment uncertainty during a crisis. Consequently, their utility function aggregates (i) the inside option, i.e., being employed by the firm, and (ii) the outside option, i.e., either being employed by another firm or receiving social transfers and enjoying leisure benefits in the case of unemployment, where aggregation reflects the level of employment within the firm or, put differently, the probability of being employed by the firm. Accordingly, employees of the firm with pre-shock employment policy $\left(L^{\text {pre }}, w^{\text {pre }}\right)$ might evaluate the firm's response to the exogenous shock according to utility function

$$
U(L, w)=\frac{L^{\text {post }}}{L^{\text {pre }}} \times u\left(w^{\text {post }}\right)+\frac{L^{\text {pre }}-L^{\text {post }}}{L^{\text {pre }}} \times u\left(w^{\text {outside }}\right)
$$

where $L^{\text {post }}\left(L^{\text {pre }}\right)$ is the post-shock (pre-shock) level of employment, $w^{\text {post }}\left(w^{\text {pre }}\right)$ is the post-shock (pre-shock) wage level and $w^{\text {outside }}$ is the (indifference) wage level of the outside option. Eq. (2) suggests that employees would prefer to "trade" wages for higher employment, particularly when the gap between the inside and outside options is large. The resulting optimization problem of the firm is illustrated in Panel C of Figure 1. The one-sided "reduce employment" solution is thus likely to be suboptimal, and a Pareto-superior solution, from the perspective of employees and employers alike, could therefore be reached if the parties could agree on a response strategy that involved a reduction in wages or the implementation of measures that reduced labor costs at the given level of employment (Aoki, 1984) ${ }^{6}$, such as temporary work absences, work-sharing agreements, restructuring of bonus systems etc. The difference between such cooperative or integrative solutions, which follow a dynamic view and ensure the maintenance of high-skilled labor, and distributive solutions, where the employers' focus is primarily on immediate cost reductions, has also been outlined in relation to the Great Recession, with scholars underscoring 
the superiority of procedural innovations that involve some form of workers' concessions in return for employment guarantees (Glassner et al., 2011).

The implementation of such cooperative response strategies is, however, subject to asymmetric information and moral hazard problems within the employee-employer negotiations. Specifically, workers know that employers may be tempted to exaggerate financial difficulties in order to justify lower wages or other concessions they demand from employees (Freeman and Lazear, 1995). Employers, on the other hand, might fear that workers will reduce their efforts following a negotiated reduction in their wages or other benefits. A mutual distrust may therefore trap the employers and employees in a prisoner's dilemma situation. That is, even if wage adjustments and other types of workers' concessions represent an efficient solution, this solution will not be reached if there is a high degree of asymmetry of information and the employees lack credible information about the state of the firm and employers' intentions (Aoki, 1984; Freeman and Lazear, 1995).

Drawing on the anecdotal evidence and previous theoretical work, we argue that the implementation of cooperative agreements during crises might be easier in companies in which employees are represented on the board of directors, compared to in other firms. First, since employees were taking part in strategic decision-making already before the crisis, the employers (i.e., shareholder representatives on the board of directors and managers) in such firms might be more experienced in negotiating with the employees in search of Pareto-superior strategies. As noted above, case-based and anecdotal evidence suggests that such experience was relevant for the implementation of plant-level agreements during the crisis (Glassner et al., 2011). Second, when both employee and shareholder (employer) representatives are present on the board of directors, they have the possibility of building up trust in stable times. This might in turn facilitate the exchange of preferences, interests and priorities in crisis times, when information becomes blurry and less tangible and trust becomes important. In sum, drawing on the accumulated trust, BLER might ensure the information exchange necessary for cooperative bargaining to occur (Aoki, 1984).

Third, by taking part in decisions regarding firms' crisis responses, employee directors might also provide credibility to other employees regarding any information conveyed by the employer. Without such credibility, workers would be reluctant to moderate their demands, make concessions or cooperate with the management. 
Fourth, in the firms with employee board representatives, the workers' sense of responsibility regarding the strategic outcomes and their willingness to cooperate with employers are likely higher than in other firms (Mizrahi, 2002). When employees take part in decisions, they are more likely to perceive them as fair and necessary (Aoki, 1984; Freeman and Lazear, 1995). The risk of workers' ex-post opportunism (e.g., a reduction of work effort due to lower wages in the sense of Akerlof and Yellen, 1990) is therefore likely to be lower in firms with employee directors (Mizrahi, 2002). This might, in turn, also increase the employers' willingness to be involved in negotiations in the first place. Drawing on the outlined arguments, we propose that, compared to other firms, the companies with worker representatives on their boards of directors (BLER firms) might be better able to implement integrative (cooperative) crisis responses to a demand shock, and consequently might less likely associate with substantial employment reductions in the wake of poorer performance during the Great Recession.

\section{$3 \quad$ Institutional Framework}

Our empirical study is based on the non-financial publicly listed firms from Denmark, Sweden and Norway (Scandinavia). Employment, wages and working conditions in Scandinavian countries have conventionally been determined within the system of collective bargaining. It is presumably this system that has, during the years, played a decisive role in ensuring a stable wage and employment growth, as well as an alignment between wages and productivity, and rather limited income inequalities in Scandinavia. Collective bargaining has also complemented the labor market legislation, generating provisions related to working hours, paid vacation, sabbaticals, a minimum wage, leave arrangements, pensions, education and training (Andersen et al., 2014). Despite some differences, the Scandinavian countries have shared a number of common characteristics of the system, such as equally strong bargaining parties on both sides, high public- and private-sector coverage, and multi-level agreements with the bargaining taking place at national, industry and company levels (Andersen et al., 2014). Over the years, the relevance of the different levels has changed to the benefit of industry- and company-level negotiations. This trend is presumably the result of the European integration, globalization, shifting markets and increasing competition and, consequently, increasing demand from employers for more flexible wage formation, which has characterized the 
wage bargaining in most of the European countries (Glassner et al., 2011). As a consequence, especially in Denmark and Sweden, the collective bargaining agreements are nowadays more like framework agreements that set limits within which wages and working hours can be negotiated locally. This, on the one hand, provides local actors with substantial rights to information and consultation rights in various areas, while on the other hand gives the employers more leeway to find the most efficient solutions in cooperation with the employees, within the more centrally defined objectives, procedures and criteria (Andersen et al. 2014).

The increased flexibility of collective bargaining systems in Scandinavia was also revealed during the Great Recession when, reportedly, it allowed for and provided a steer and procedural certainty for much faster company-level cost adjustment compared to more decentralized systems (Andersen et al., 2014; Glassner et al., 2011). While the countries varied in terms of available mechanisms for labor market adjustments, the local actors in Denmark, Norway and Sweden had the possibility not just to cut employment ${ }^{7}$ but also to work out alternative solutions or mechanisms that would enable them to avoid substantial dismissals during the crisis (Svalund et al., 2013; Glassner et al., 2011). The companies could choose between a set of other measures, alternatives to dismissals, such as reorganizing bonus systems (i.e., Denmark), renegotiating existing flexible time agreements, negotiating new types of work-sharing agreements, temporary furloughs (Denmark and Norway), and reductions of working time (Sweden). In certain cases, innovative types of solutions were developed, such as reduced work weeks, rotational periods of work and extended vacations (Svalund et al., 2013; Glassner et al., 2011) ${ }^{8}$. Regardless of the form adopted, these adjustments likely required extensive cooperation between employers (management) and employees, as solutions had to be acceptable to both parties (Svalund et al., 2013). Reflecting this, case evidence from companies across Europe suggests that crisis-induced restructuring has frequently led to contestation between management and workforce; the workers' resistance to concessions, such as reduced hours, temporary elimination of and reductions in bonus payments etc. often constituted a key cause for the failures in the implementation of company-level agreements (Glassner et al., 2011).

In the present study we focus on employee directors on corporate boards (board-level employee representation, BLER) and their role as facilitators of cooperative company-level labor cost adjustments during the Great Recession. In Scandinavia, the employees of firms of a certain size (minimum 35 full-time employees in Denmark, 
30 in Norway and 25 in Sweden) are granted the option of installing employee representation on the board of directors. That is, in order to be represented on the board, the employees have to propose and jointly support the introduction of such representation. In Denmark, for example, the proposal to establish such a representation can be put forward by 10 percent of the employees or a trade union representing that percentage. This option is then implemented if supported by the majority of the employees in the firm. The rights to be represented on the board of directors have been in place since the late seventies. Consequently, many of the larger and mature publicly listed firms have had such a representation in place for decades. The representatives on the board are elected by the employees of the firm, normally for a four-year term, and must be employed by the same company or business group. When elected, employee directors generally hold about a third of board seats, and are never a majority on the board ${ }^{9}$. Employee directors have the same rights and obligations as shareholder-elected members of the board; as members of the board, they play an important role in firms' strategic decisions, including decisions on major dismissals (Hansen, 2003).

During the Great Recession, the intermediaries at the industry and company levels were reportedly instrumental in facilitating the implementation of solutions that involved workers' concessions in exchange for some form of employment guarantee (Glassner et al., 2011). Based on our reading of the theoretical and empirical (casebased) literature, we in this paper assign the employee directors a central role in these company-level negotiations. Thus, we expect the effect of BLER on the implementation of cooperative solutions to be additive to the impact of other related institutions, such as labor unions or works councils. As described by Svalund et al. (2013), the unions in Scandinavia played a key role in negotiating adjustments in the central and sector-level regulation, which in turn facilitated the negotiations at the firm level. In firms, the strategic decisions with regards to cost adjustments were often taken at higher organizational levels (Svalund et al., 2013), such as the board of directors. These observations are in line with the tradition of employee board representation in Scandinavia. Specifically, the right to workers' representation on the board of directors was instituted with the aim of providing a platform for employeeemployer cooperation, with a view in turn at aiding the long-term competitiveness and success of Scandinavian firms (Jackson, 2005). 


\section{$4 \quad$ Empirical Analysis}

\subsection{Data, sample characteristics and key trends}

To test our theoretical propositions, we rely on the population of non-financial firms operating in Scandinavia (Denmark, Sweden and Norway). For the purpose of the analysis, we hand-collected information on these companies' boards of directors from annual reports and other sources, and supplemented these data with financial data (Worldscope) and ownership data (Bureau van Dijk) spanning the period 2004-2010. ${ }^{10}$ Our final sample covers 365 unique Scandinavian firms (84 firms from Denmark, 109 from Norway, and 172 from Sweden). Based on this information, we define a number of variables. Foremost, we define BLER as the dummy variable that classifies the firms according to whether or not, at the end of 2007, they had at least one employee-elected director on the board (BLER=1). Among the 365 Scandinavian firms in the sample, 193 firms (or some 53 percent of all firms) have employee directors on board (BLER $=1$ ), while 172 companies have no employee directors $(\mathrm{BLER}=0)$. Thereby, it is interesting to note that the sample is remarkably balanced even within countries: While 60 percent of our Danish firms have employee representatives on the board (50 out of the 84 firms), 53 percent of our Norwegian firms and 49 percent of our Swedish firms are BLER firms.

To allow for more granular analysis, we also define Relative BLER (\%), which measures the share of all board seats held by employee-elected directors at the end of 2007, as a percentage. Figure 2 illustrates the distribution of the firms in our sample based on the percentage of board seats held by employee elected members. 
Figure 2: Distribution of firms by share of employee-elected board members, by country
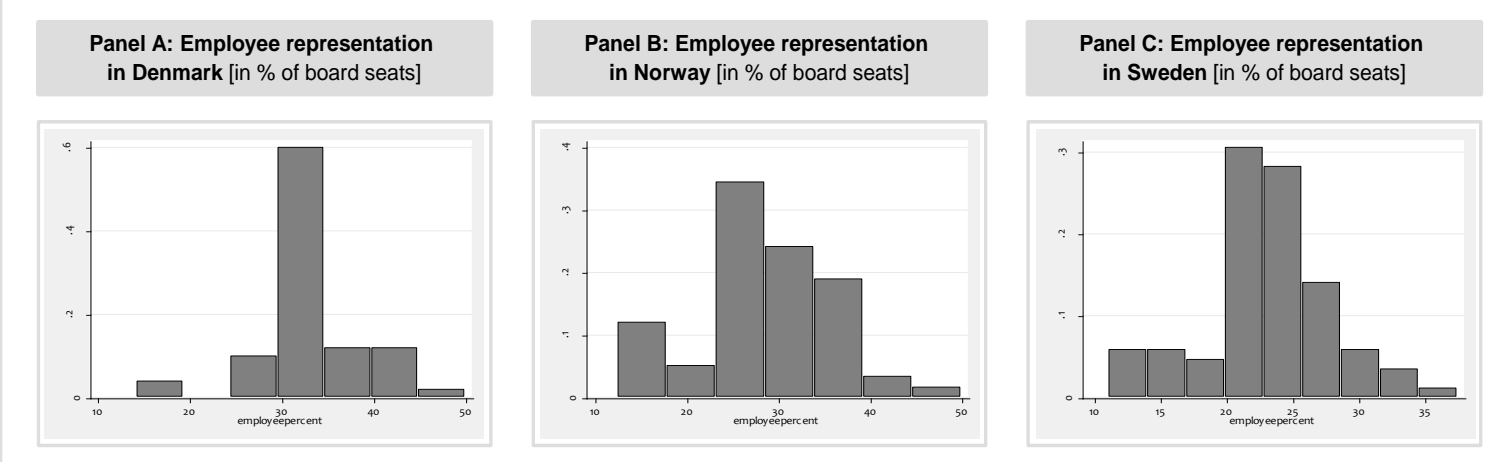

Notes: This figure illustrates the distribution of BLER firms according to the relative importance of employee-elected board members in each of the countries studied (measured as the fraction of board members that are elected by employees). 
To analyze labor costs adjustments during the Great Recession, we define two key variables, namely the variable Labor Costs per Employee, which is the total salaries and benefit expense standardized by number of employees, and a dummy variable, labeled $45+$ Percent, indicating firm-years that associate with a (forward looking) reduction in the number of firm employees of at least 5 percent. ${ }^{11}$ The choice of the latter variable follows the scholarly evidence that has previously identified a link between board structure and employment policies in Scandinavia (e.g., Matsa and Miller, 2013). The 5 percent decrease in the number of employees, as a measure of relevant reduction in employment, is also in line with the EU definition of collective redundancies. Specifically, according to the EU, any dismissal of 30 or more employees from a large firm should be considered a collective redundancy. This number (30) represents about 5 percent of all employees for the median firm in our sample (639 employees). For robustness, we define two additional employment measures, namely the $\Delta 10+$ Percent variable indicating the firm years that associate with a decrease in the number of firm employees by at least 10 percent. Relatedly, the $\Delta$ variable (censored at zero) measures the negative employment growth (not in percent).

Our regression specifications include a number of other variables, such as firm size, governance characteristics, industry-level union density (Unionization) and other firm characteristics. We measure firm size by the value of total assets, in logarithms (Size). We chose to use firm assets rather than the total number of firm employees to avoid multicollinearity problems in the empirical analysis. While they correlate highly with the firms' number of employees, the total assets are less strongly correlated with the BLER dummy compared to the variable capturing the total number of firm employees. Our performance measure is return on assets $(R O A)$, defined as the EBIT (Earnings before Interest and Taxes standardized by total assets), as a percentage. Alternatively, we measure firm performance by the Sales' margin (EBIT to Total Revenues, as a percentage) and ROE (Net income to Equity, as a percentage). We measure the tangibility of firm assets by the net value of property, plant and equipment (PPE) standardized by total assets (Tangibility), as a percentage, and research intensity by research and development expenses standardized by total assets $(R n D$, in \%). Leverage is defined as total debt to total assets, as a percentage. Age is the logarithm of the years since the firm's establishment. Finally, Block captures the percentage of ownership held by the firm's largest owner. All variables and source of data used to construct the variables are described in detail in Table 1. 
Table 1: Definition of main variables and their sources

\begin{tabular}{|c|c|c|}
\hline Variable label & Variable description & Source \\
\hline \multicolumn{3}{|c|}{ Board-level employee representation } \\
\hline BLER & $\begin{array}{l}\text { Dummy for having (at least one) employee-elected di- } \\
\text { rector on the board (in 2007) }\end{array}$ & Annual reports and corporate websites \\
\hline BLER (\%) & $\begin{array}{l}\text { Share of all board seats held by employee-elected di- } \\
\text { rectors (in 2007) }\end{array}$ & Annual reports and corporate websites \\
\hline \multicolumn{3}{|l|}{ Employment policy } \\
\hline$\Delta 5+$ percent & $\begin{array}{l}\text { Dummy indicating a reduction of firm employment of } \\
\text { at least } 5 \text { percent }\end{array}$ & $\begin{array}{l}\text { Own calculation based on Thomson/Reu- } \\
\text { ters Worldscope }\end{array}$ \\
\hline$\Delta 10+$ percent & $\begin{array}{l}\text { Dummy indicating a reduction of employment of least } \\
10 \text { percent }\end{array}$ & $\begin{array}{l}\text { Own calculation based on Thomson/Reu- } \\
\text { ters Worldscope }\end{array}$ \\
\hline$\Delta$ & $\begin{array}{l}\text { A censored (at zero) variable measuring negative em- } \\
\text { ployment growth }\end{array}$ & $\begin{array}{l}\text { Own calculation based on Thomson/Reu- } \\
\text { ters Worldscope }\end{array}$ \\
\hline Labor Costs per Employee & $\begin{array}{l}\text { Total salary and benefit expense standardized by } \\
\text { number of employees }\end{array}$ & $\begin{array}{l}\text { Own calculation based on Thomson/Reu- } \\
\text { ters Worldscope }\end{array}$ \\
\hline Labor intensity & $\begin{array}{l}\text { Labor force (number of employees) per } 1 \text { mill USD } \\
\text { revenue }\end{array}$ & $\begin{array}{l}\text { Own calculation based on Thomson/Reu- } \\
\text { ters Worldscope }\end{array}$ \\
\hline Labor costs per revenues & $\begin{array}{l}\text { Total salaries and benefit expense standardized by } \\
\text { revenues }\end{array}$ & $\begin{array}{l}\text { Own calculation based on Thomson/Reu- } \\
\text { ters Worldscope }\end{array}$ \\
\hline \multicolumn{3}{|c|}{ Accounting-based firm characteristics } \\
\hline Size & Logarithm of total assets (in 000 USD) & Thomson/Reuters Worldscope \\
\hline ROA & EBIT standardized by total assets (in \%) & $\begin{array}{l}\text { Own calculation based on Thomson/Reu- } \\
\text { ters Worldscope }\end{array}$ \\
\hline Tangibility & $\begin{array}{l}\text { Net property, plant and equipment standardized by to- } \\
\text { tal assets (in \%) }\end{array}$ & $\begin{array}{l}\text { Own calculation based on Thomson/Reu- } \\
\text { ters Worldscope }\end{array}$ \\
\hline $\mathrm{RnD}$ & $\begin{array}{l}\text { Research and development expenses standardized } \\
\text { by total assets (in \%) }\end{array}$ & $\begin{array}{l}\text { Own calculation based on Thomson/Reu- } \\
\text { ters Worldscope }\end{array}$ \\
\hline Leverage & $\begin{array}{l}\text { Short- and long-term debt standardized by total as- } \\
\text { sets (in \%) }\end{array}$ & $\begin{array}{l}\text { Own calculation based on Thomson/Reu- } \\
\text { ters Worldscope }\end{array}$ \\
\hline \multicolumn{3}{|c|}{ Other firm and governance characteristics } \\
\hline Capital Location & Dummy for firms headquartered in the capital region & $\begin{array}{l}\text { Own calculation based on Bureau van Dijk } \\
\text { data }\end{array}$ \\
\hline Age & $\begin{array}{l}\text { Number of years since firm establishment, in loga- } \\
\text { rithms }\end{array}$ & $\begin{array}{l}\text { Own calculation based on Bureau van Dijk } \\
\text { data }\end{array}$ \\
\hline CEO & $\begin{array}{l}\text { Board Composition variable, measuring whether the } \\
\text { CEO is a member of the board of directors }\end{array}$ & Annual reports and corporate websites \\
\hline Blockholder & $\begin{array}{l}\text { Fraction of ownership owned by largest blockholder, } \\
\text { as a percentage }\end{array}$ & Bureau van Dijk \\
\hline Family & $\begin{array}{l}\text { Dummy for firms controlled by families or an owner } \\
\text { with disproportional control rights }\end{array}$ & $\begin{array}{l}\text { Annual reports and corporate websites } \\
\text { Bureau van Dijk }\end{array}$ \\
\hline \multicolumn{3}{|l|}{ Other variables } \\
\hline Unionization & Industry-level union density, as a percentage & Andersen et al. (2014). \\
\hline BLER Industry & $\begin{array}{l}\text { Percentage of other firms in the industry that have } \\
\text { employee directors on board }\end{array}$ & $\begin{array}{l}\text { Own calculation based on annual reports } \\
\text { and corporate websites }\end{array}$ \\
\hline BLER Region & $\begin{array}{l}\text { Percentage of other firms in the region that have em- } \\
\text { ployee directors on board }\end{array}$ & $\begin{array}{l}\text { Own calculation based on annual reports } \\
\text { and corporate websites }\end{array}$ \\
\hline
\end{tabular}

Notes: This table reports definitions and sources of our main variables. 
Table 2 reports descriptive statistics for our variables as of the end of 2007. Employee directors are found in 53 percent of our sample firms and hold 15 percent of all board seats. When on the board, these directors on average hold around a third of board seats (27.77 percent, see average value under BLER=1), i.e., about two seats on average. In line with the legal provisions (see footnote 9), the percentage of seats held by employee directors varies across countries; the highest percentage is observed in Denmark (34 percent on average), followed by Norway (30 percent) and then Sweden (23 percent). The firms with employee directors were, in the year 2007, in many aspects different from the firms without employee directors. They were, among others, larger, older, more indebted but also relatively more profitable than the firms without employee directors. The higher incidence of employee representation among the larger and older firms is partly due to the fact that, in many of the firms in our sample, the employee board representation was established within the supportive political climate that existed during the late seventies, and has been maintained ever since (for more, see for example Gregorič and Poulsen, 2018). 
Table2: Descriptive statistics

\begin{tabular}{|c|c|c|c|c|c|c|c|c|c|c|c|c|c|}
\hline \multirow{2}{*}{ Variable } & \multicolumn{6}{|c|}{ Full sample } & \multicolumn{3}{|c|}{ BLER = 0} & \multicolumn{3}{|c|}{ BLER = 1} & \multirow{2}{*}{ Diff } \\
\hline & $\mathbf{N}$ & Mean & SD & P25 & Median & P75 & $\mathbf{N}$ & Mean & SD & $\mathbf{N}$ & Mean & SD & \\
\hline BLER & 365 & 0.53 & 0.50 & 0.00 & 1.00 & 1.00 & 172 & 0.00 & 0.00 & 193 & 1.00 & 0.00 & n.a. \\
\hline Relative BLER (\%) & 365 & 0.15 & 0.15 & 0.00 & 0.14 & 0.29 & 172 & 0.00 & 0.00 & 193 & 0.28 & 0.08 & $-47.53^{\star * *}$ \\
\hline BoardSize & 365 & 7.17 & 2.12 & 5.00 & 7.00 & 9.00 & 172 & 5.65 & 1.34 & 193 & 8.52 & 1.73 & $-17.60^{* * *}$ \\
\hline Employees & 354 & 4,822 & 17,057 & 199 & 639 & 2,630 & 165 & 908 & 2,056 & 189 & 8,239 & 22,746 & $-4.12^{\star \star \star}$ \\
\hline Employment intensity & 351 & 1.07 & 8.89 & 0.22 & 0.35 & 0.50 & 162 & 1.77 & 13.06 & 189 & 0.47 & 0.66 & 1.36 \\
\hline Labor costs per employee & 352 & 105.43 & 232.24 & 64.99 & 83.31 & 105.94 & 165 & 134.23 & 335.97 & 187 & 80.01 & 29.55 & $2.20^{*}$ \\
\hline Size & 365 & 12.44 & 1.89 & 11.06 & 12.33 & 13.60 & 172 & 11.67 & 1.65 & 193 & 13.13 & 1.81 & $-8.02^{\star \star \star}$ \\
\hline Tangibility & 365 & 79.98 & 18.59 & 69.24 & 84.42 & 96.56 & 172 & 79.61 & 19.77 & 193 & 80.30 & 17.52 & -0.35 \\
\hline $\mathrm{RnD}$ & 365 & 2.84 & 7.04 & 0.00 & 0.00 & 1.82 & 172 & 2.93 & 7.06 & 193 & 2.75 & 7.04 & 0.25 \\
\hline ROA & 365 & 4.88 & 18.34 & 2.09 & 7.27 & 12.91 & 172 & 1.98 & 20.24 & 193 & 7.46 & 16.08 & $-2.88^{* *}$ \\
\hline Leverage & 365 & 22.84 & 18.36 & 6.94 & 19.89 & 37.14 & 172 & 20.56 & 19.11 & 193 & 24.86 & 17.47 & $-2.25^{*}$ \\
\hline InAge & 365 & 3.12 & 0.84 & 2.64 & 3.00 & 3.74 & 172 & 2.88 & 0.73 & 193 & 3.34 & 0.87 & $-5.39^{* * *}$ \\
\hline Family & 343 & 0.21 & 0.41 & 0.00 & 0.00 & 0.00 & 161 & 0.18 & 0.39 & 182 & 0.24 & 0.43 & -1.27 \\
\hline Block & 365 & 51.42 & 24.54 & 32.80 & 53.70 & 72.86 & 172 & 46.91 & 25.67 & 193 & 55.45 & 22.80 & $-3.36^{\star \star \star}$ \\
\hline CEO & 365 & 0.32 & 0.47 & 0.00 & 0.00 & 1.00 & 172 & 0.30 & 0.46 & 193 & 0.33 & 0.47 & -0.72 \\
\hline Capital & 365 & 0.54 & 0.50 & 0.00 & 1.00 & 1.00 & 172 & 0.59 & 0.49 & 193 & 0.49 & 0.50 & 1.82 \\
\hline Unionization & 365 & 60.50 & 18.49 & 48.00 & 57.00 & 79.00 & 172 & 57.80 & 18.66 & 193 & 62.91 & 18.05 & $-2.66^{\star *}$ \\
\hline BLER_Industry & 365 & 42.09 & 22.01 & 25.00 & 42.86 & 55.56 & 172 & 37.03 & 20.51 & 193 & 46.59 & 22.37 & $-4.24^{\star * *}$ \\
\hline BLER Region & 365 & 50.90 & 14.19 & 42.73 & 45.65 & 56.90 & 172 & 50.37 & 12.96 & 193 & 51.36 & 15.22 & -0.66 \\
\hline
\end{tabular}

Notes: This table reports descriptive statistics for our main variables in our last pre-crisis year, i.e. 2007. All variables are symmetrically winsorized at the $1 \%$ level, with the exception of BLER and Relative BLER (\%). All variables are described in detail in Table 1.

Significance levels: $* \mathrm{p}<0.10, * * \mathrm{p}<0.05, * * * \mathrm{p}<0.01$. 
The aim of this paper is to analyze the differences in companies' responses to the demand shocks during the Great Recession. In particular, in our theoretical section we argued that the companies with board-level employee representation (BLER) might be better able to negotiate agreements that allow for labor costs adjustments without substantial decreases in employment. As a first inspection into this issue, Figures 3 and 4 below illustrate the forward-looking employment trends over the 2004-2010 period, thus covering the pre-crisis, the crisis period and, with 2010, a year that we consider post crisis. While Figure 3 illustrates the overall market trend, both in terms of total employment growth as well as with regard to the incidence of employment reductions, Figure 4 provides corresponding insights into univariate differences between the firms with board-level employee representation (BLER firms) and other firms (non-BLER firms). 
Figure 3: Employment growth and substantial employment reductions over time

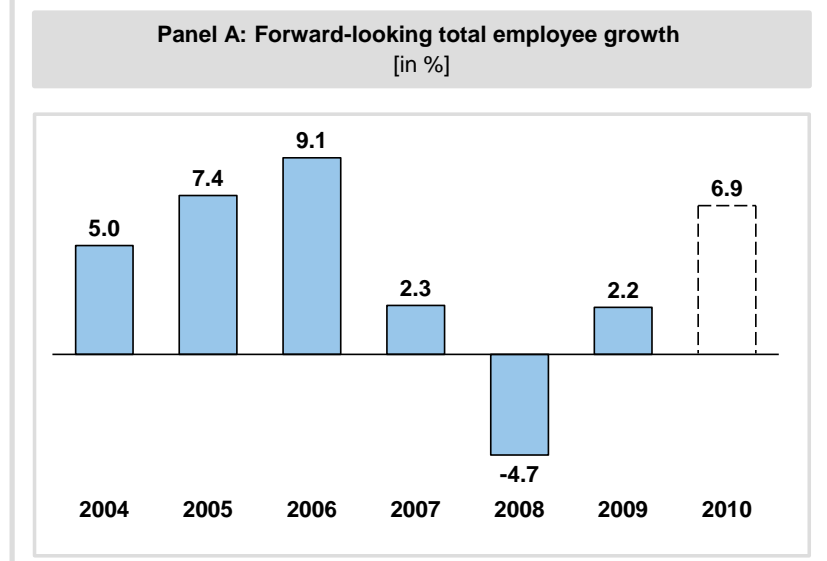

Panel B: Forward-looking proportion of firms reducing employment [in \%]

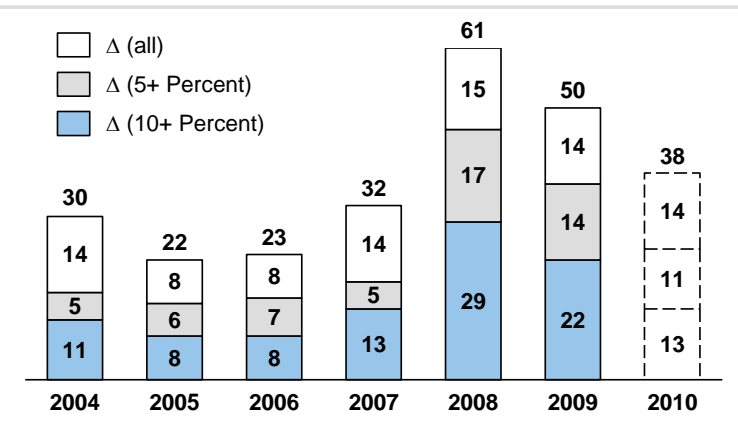

Notes: This figure illustrates overall development of employment within our sample of Scandinavian non-financial listed firms over the sample period. Specifically, Panel A reports the development of total employment (employee-weighted mean values over all firms) and Panel B the proportion of firms with (substantial) employment reductions (unweighted mean values of corresponding dummy variables). $\Delta$ (all) refers to the proportion of firms with any reduction of employment (i.e., firms with negative employment growth).

Figure 4: Employment growth and substantial employment reductions over time for BLER and non-BLER firms
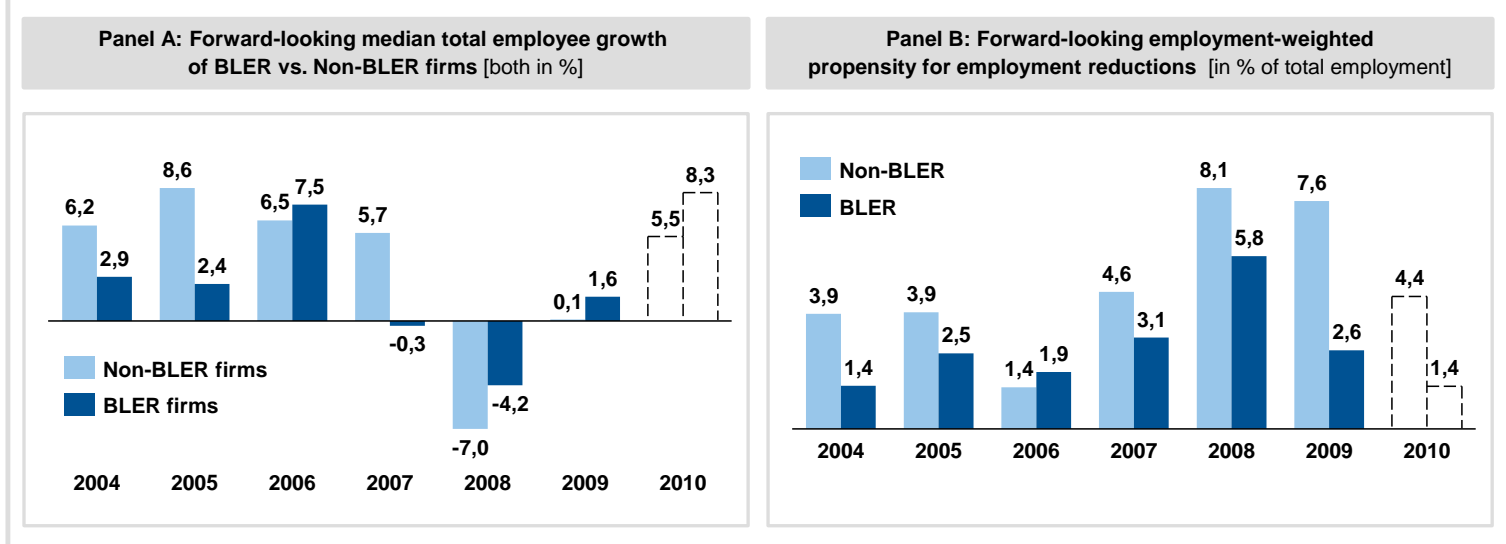

Notes: This figure contrasts the development of employment in BLER firms within our sample of Scandinavian non-financial listed firms versus that of non-BLER firms over the sample period. Specifically, Panel A reports the median development of total employment (employee-weighted median values) and Panel B reports the employment-weighted propensity of employment reductions (employee-weighted mean values of employment reductions, if any). 
As anticipated, we observe that, overall, the employment growth was significantly lower (or negative), and the incidence of at least 5(10) percent employment reductions was higher during the years of Great Recession. As illustrated in Figure 3, during the pre-crisis period, the share of companies in our sample that experienced reductions in the number of employees by at least 5 percent ranged between 14 and 18 percent; during the crisis years, the share of such firms reached and exceeded 40 percent. We observe a similar pattern when examining the trends in relation to employment reductions of at least 10 percent of the workforce.

In Figure 4, we compare BLER and non-BLER companies and the related forward-looking employment growth and propensity to reduce employment. The histograms in panel A and B of Figure 4 point to some relevant differences in terms of employment dynamics in BLER and non-BLER firms. Generally, looking at the pre-crisis period, we observe that BLER firms associate with slower growth in employment, compared to non-BLER firms; the BLER firms are however also more averse to employment reductions (panel B). These differences seem to be confirmed also during the Great Recession, where non-BLER firms experienced substantially higher employment reductions compared to the BLER firms. Both figures also suggest that with regard to our forward looking employment indicators the main shock was observed in the years 2008 and 2009 rationalizing our crisis definition from above. Furthermore, eyeball inspection of Figure 4 suggests that the crisis impact was not only less severe for BLER firms, but also that the shock did not last as long as in non-BLER firms, allowing BLER firms to recover faster at least with regard to their employment.

Next we dig a little deeper into the differences in firms' behavior by inspecting the various components of firms' labor costs during the crisis years. Thereby, while we start with a simple measure, i.e., the average labor cost per employee of the firm, we also acknowledge that labor costs have to be put into perspective of the firm's level of business. Thus, we also look at the relative importance of employment and the relative importance of labor costs by putting both into perspective to the topline of a firm's profit and loss statement, namely its revenues. Specifically, Table 3 reports the estimates of basic, cross-sectionally organized OLS regressions, where we relate a specific labor costs component, i.e., the Labor costs per employee (in logarithms) and Labor intensity (Number of Employees/Total Firm Revenues, in logarithms), and the relative importance of the labor costs, measured by Labor costs per Revenues, (in logarithms) at the end of year 2010 to our pre-crisis BLER dummy. Thereby, we 
control for a basic set of controls (i.e., firm size measured by the number of employees, leverage, blockownership all measured pre-crisis in 2006, as well as industry and country fixed effects), implemented changes in the employment during the crisis period (Delta Employees, ln from 2006-2010), and the pre-crisis (year 2006) levels of the selected dependent variables. 
Table 3: Wage costs adjustments during crisis: First investigation between BLER and non-BLER firms

\begin{tabular}{|c|c|c|c|}
\hline $\begin{array}{l}\text { Dependent variable } \\
\text { [values measured in 2010] } \\
\text { Method } \\
\text { Specification }\end{array}$ & $\begin{array}{c}\text { Labor costs } \\
\text { per employee (In) } \\
\text { I }\end{array}$ & $\begin{array}{l}\text { Labor intensity (In) } \\
\text { OLS } \\
\text { II }\end{array}$ & Labor costs per revenues (In) \\
\hline BLER & $\begin{array}{c}-0.137^{* *} \\
{[-2.53]}\end{array}$ & $\begin{array}{c}0.166^{\star *} \\
{[2.13]}\end{array}$ & $\begin{array}{l}0.057 \\
{[0.65]}\end{array}$ \\
\hline Employees (In) [in 2006] & $\begin{array}{l}-0.002 \\
{[-0.16]}\end{array}$ & $\begin{array}{l}-0.046 \\
{[-1.32]}\end{array}$ & $\begin{array}{l}-0.064 \\
{[-1.29]}\end{array}$ \\
\hline Delta Employees (In) [from 2006-10] & $\begin{array}{c}-0.403^{\star * *} \\
{[-5.96]}\end{array}$ & $\begin{array}{c}0.413^{* * *} \\
{[4.56]}\end{array}$ & $\begin{array}{l}0.011 \\
{[0.10]}\end{array}$ \\
\hline Leverage [in 2006] & $\begin{array}{c}-0.005^{\star *} \\
{[-2.20]}\end{array}$ & $\begin{array}{c}0.009^{* * *} \\
{[3.05]}\end{array}$ & $\begin{array}{l}0.003 \\
{[0.79]}\end{array}$ \\
\hline Block [in 2006] & $\begin{array}{l}0.002 \\
{[1.23]}\end{array}$ & $\begin{array}{l}0.002 \\
{[1.30]}\end{array}$ & $\begin{array}{c}0.004^{\star *} \\
{[2.06]}\end{array}$ \\
\hline Labor costs per employee (In) [in 2006] & $\begin{array}{c}0.775^{\star * *} \\
{[7.62]}\end{array}$ & & \\
\hline Labor intensity (In) [in 2006] & & $\begin{array}{c}0.628^{\star * *} \\
{[7.11]}\end{array}$ & \\
\hline Labor costs per revenues (In) [in 2006] & & & $\begin{array}{c}0.605^{\star * *} \\
{[5.24]}\end{array}$ \\
\hline Industry effects & yes & yes & yes \\
\hline Country effects & yes & yes & yes \\
\hline Observations & 202 & 204 & 201 \\
\hline Adj. $R^{\wedge} 2$ & 0.635 & 0.556 & 0.550 \\
\hline
\end{tabular}

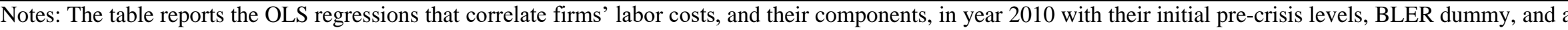

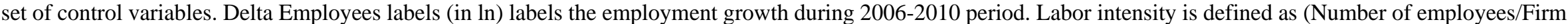
revenues), in logarithms. See also Table 1 . Numbers in brackets are t-values robust to heteroscedasticity.

Significance levels: $* \mathrm{p}<0.10, * * \mathrm{p}<0.05, * * * \mathrm{p}<0.01$. 
The results reported in Table 3 indicate that in 2010 BLER firms ceteris paribus had lower Labor costs per employee, but higher employment levels (as measured by Labor intensity) compared to non-BLER firms. ${ }^{12}$ This is consistent with the view that during the crisis, compared to other firms, BLER firms had a lower propensity to reduce employment, but put more pressure on wages. Interestingly, the net effect of these two mechanisms seems to be zero. Indeed, when it comes to total labor costs (Labor costs per Revenues in Specification III), there seems to be no differences between BLER and non-BLER firms. These (preliminary) results suggest that both BLER and non-BLER firms were similarly efficient in adjusting their labor costs during crisis, but the mechanism through which these adjustments occurred likely differed between the two sub-groups of firms, with BLER firms probably preferring higher employment levels in exchange for stronger adjustments in the labor costs per employee.

\subsection{BLER distribution across firms}

A key issue in our empirical analysis of the influence of board-level employee representation (BLER) on firm behavior during the Great Recession, which we present in the subsequent sections, relates to the fact that BLER is not randomly distributed across firms. As illustrated in Table 2 above, BLER firms are systematically different from non-BLER firms in terms of firm size, age, and a number of other characteristics. Failing to control for these characteristics when studying the impact of BLER on firm behavior might lead to biased and inconsistent estimates of our coefficients of interest. To mitigate these issues, we next look deeper into the distribution of employee directorships. Specifically, we estimate a probit regression using a dummy for the presence of at least one employee-elected member on the board of directors in the year 2007 as the dependent variable $(B L E R)$ and a set of firm-specific covariates in the same year. We report the results in Table 4. Specification (I) is our basic specification; in Specification (II) we add firm ownership structure, namely the fraction of shares held by the firm's largest owner (Block) and a dummy capturing family control or the presence of owners with a long-term commitment due to disproportionate control (Family). Scholars have previously noted that family owners might be more sympathetic to workers' interests and internalize them within the decision-making (Lins et al., 2013). Consequently, employees might find it less valuable to be represented on the boards of such firms. Specifications (I) and (II) also include industry and country fixed effects ${ }^{13}$. 
The results tabulated in Table 4, Specifications (I) and (II), show that employee board representation is positively related to firm size and age; employees are more likely to be represented on the boards of researchintensive firms (see the coefficient for $R n D$ measuring firms' investments in research and development, standardized by total firm assets). These results are in line with transaction costs literature on employee voice, which suggests that workers are more likely to implement board-level employee representation in the firms where such representation is more beneficial for them (Willman et al., 2014; Gregorič and Poulsen, 2018). While we find no significant relationship between BLER and family control, we observe that the companies with employee directors have on average higher levels of ownership concentration (Block), compared to other firms. The positive relationship between ownership concentration and the presence of BLER indicates that, in BLER firms, the shareholders might want to counterbalance employee power by increasing their ownership share and, consequently, their influence on the board of directors. This evidence is in line with scholarly view on the nature of employee codetermination in Scandinavia (Jackson, 2005) describing this system as a platform for cooperation between employees and (influential) owners, rather than as a system through which employees might be able to direct firm policies. Accordingly, we in this paper propose that the board-level employee representation might act as a facilitator of agreements that are either mutually beneficial or that increase workers' benefits without harming the employers (shareholders), rather than solely benefiting the employees at the cost of shareholder value (for more on this, see also section 4.4). 
Table 4: Determinants of BLER (year 2007)

\begin{tabular}{|c|c|c|c|c|c|}
\hline \multirow{3}{*}{$\begin{array}{l}\text { Dependent variable } \\
\text { Method } \\
\text { Sample } \\
\text { Specification }\end{array}$} & \multicolumn{3}{|c|}{ BLER } & \multicolumn{2}{|c|}{ BLER(\%) } \\
\hline & \multicolumn{3}{|c|}{ Probit } & \multicolumn{2}{|c|}{ OLS } \\
\hline & I & II & III & IV & v \\
\hline \multirow[t]{2}{*}{ Size } & $0.317^{\star \star *}$ & $0.334^{\star * *}$ & $0.317^{* \star *}$ & $2.254^{\star * *}$ & $2.481^{* * *}$ \\
\hline & {$[5.50]$} & [5.69] & {$[5.77]$} & [5.02] & {$[5.08]$} \\
\hline \multirow[t]{2}{*}{ Tangibility } & -0.006 & -0.007 & $-0.007^{*}$ & -0.039 & $-0.063^{\star}$ \\
\hline & {$[-1.21]$} & {$[-1.39]$} & {$[-1.68]$} & {$[-0.95]$} & {$[-1.67]$} \\
\hline \multirow[t]{2}{*}{$\mathrm{RnD}$} & $0.029^{* *}$ & $0.029^{\star *}$ & $0.023^{*}$ & $0.215^{\star *}$ & $0.210^{*}$ \\
\hline & [2.24] & [2.14] & {$[1.86]$} & [1.98] & {$[1.85]$} \\
\hline \multirow[t]{2}{*}{ ROA } & 0.001 & 0.003 & 0.002 & 0.036 & 0.052 \\
\hline & {$[0.20]$} & {$[0.45]$} & {$[0.47]$} & {$[0.84]$} & {$[1.19]$} \\
\hline \multirow[t]{2}{*}{ Leverage } & -0.003 & -0.006 & -0.006 & -0.014 & -0.061 \\
\hline & {$[-0.62]$} & {$[-1.09]$} & {$[-1.34]$} & {$[-0.30]$} & {$[-1.35]$} \\
\hline \multirow[t]{2}{*}{ Age } & $0.352^{* \star *}$ & $0.304^{* *}$ & $0.343^{* * *}$ & $2.363^{* *}$ & $2.955^{\star *}$ \\
\hline & [2.95] & [2.45] & [2.98] & [2.18] & [2.53] \\
\hline \multirow[t]{2}{*}{ Family } & & -0.276 & -0.154 & & -2.817 \\
\hline & & {$[-1.19]$} & {$[-0.79]$} & & {$[-1.54]$} \\
\hline \multirow[t]{2}{*}{ Block } & & $0.011^{* * *}$ & $0.008^{* *}$ & & $0.078^{* *}$ \\
\hline & & [3.03] & [2.28] & & {$[2.55]$} \\
\hline \multirow[t]{2}{*}{ CEO } & & & -0.073 & & -1.631 \\
\hline & & & {$[-0.39]$} & & {$[-0.94]$} \\
\hline \multirow[t]{2}{*}{ Capital } & & & $-0.399^{\star *}$ & & -2.682 \\
\hline & & & [-2.23] & & {$[-1.62]$} \\
\hline \multirow[t]{2}{*}{ Unionization } & & & 0.001 & & 0.066 \\
\hline & & & {$[0.22]$} & & [1.15] \\
\hline \multirow[t]{2}{*}{ BLER Industry } & & & $0.013^{* * *}$ & & $0.093^{\star * *}$ \\
\hline & & & [3.49] & & [2.63] \\
\hline \multirow[t]{2}{*}{ BLER Region } & & & -0.003 & & -0.009 \\
\hline & & & {$[-0.52]$} & & {$[-0.14]$} \\
\hline Industry effects & yes & yes & no & yes & no \\
\hline Country effects & yes & yes & yes & yes & yes \\
\hline Observations & 351 & 329 & 329 & 365 & 343 \\
\hline Adj. $R^{\wedge} 2$ & & & & 0.259 & 0.230 \\
\hline
\end{tabular}

Notes: This table reports cross-sectional probit and OLS regressions that correlate BLER status and Relative BLER (\%) in 2007, our last pre-crisis year, with firm and governance characteristics, as well as industry and geographic characteristics. All variables are described in detail in Table 1 . Numbers in brackets are t-values robust to heteroscedasticity.

Significance levels: ${ }^{*} \mathrm{p}<0.10,{ }^{* *} \mathrm{p}<0.05, * * * \mathrm{p}<0.01$. 
We also observe that BLER is significantly related to a number of industry effects (coefficients for industry dummies not reported for the sake of space). To investigate industry characteristics in more detail, we in Specification (III) replace the industry dummies with two industry-level variables, namely a variable measuring union density (Unionization) and a variable measuring the percentage of other firms in the industry that have BLER (BLER Industry) ${ }^{14}$. To ensure comparability across the three Scandinavian countries, we use union density information provided in Andersen et al. (2014). This information refers to the year 2008 and is based on a broader industry classification, thereby distinguishing between public-sector firms, manufacturing, construction, retail and wholesale trade, hotels and restaurants, transport and finance. In Specification (III), we include a few additional factors that might correlate with the employees' decision to be represented on the board. Specifically, to account for regional characteristics, we include a dummy for firms whose headquarters are based in the capital city (Capital Location), and the percentage of other firms in the region that have employee directors on their boards (BLER Region). We expect that workers will feel a stronger need to be represented in firms outside the capital region, where alternative employment opportunities might be more limited. We also include a dummy for the presence of the $\mathrm{CEO}$ on the board of directors $(C E O)^{15}$; as a corporate insider, the $\mathrm{CEO}$ might facilitate information exchange between workers and shareholders, thereby potentially reducing employees' motivation to be represented on the board.

Based on the results from Specification (III), we conclude that employees are more likely to demand BLER in the firms operating in the industries with an overall higher incidence of employee representation (see the positive coefficient for BLER Industry). In line with our expectations, employee directors are less common in the firms headquartered in the capital city; apart from this, employee representation does not concentrate in specific regions. The relationship between union density (Unionization) and employee board representation is positive but not statistically significant; we also observe no significant relationship between the CEO presence on board and the incidence of BLER. As a further robustness check, we also estimate two additional specifications, using an alternative definition of employee representation, namely the share of employee directors on the board (Relative BLER 
$(\%)$ ) in Specifications (IV) and (V), Table 4. We find that the percentage of employee directors positively correlates with firm size, age, research intensity and ownership concentration, as well as sector characteristics. Overall, these results are in line with what is reported in Specifications (I)-(III). ${ }^{16}$

To provide further insights into our data and to illustrate the degree of heterogeneity between BLER and non-BLER firms, we use the Specifications (I) -- (III) to predict propensity scores and plot them in Figure 5 below. While the figure documents that there is substantial overlap between the associated density functions and thus suggests that in the following we may start with pooled regressions, it also indicates that to corroborate our findings a matched sample approach should be used as a robustness test. 


\section{Figure 5: Predicted probability of BLER status}

Panel A: Prediction based on determinants regression, Specification I

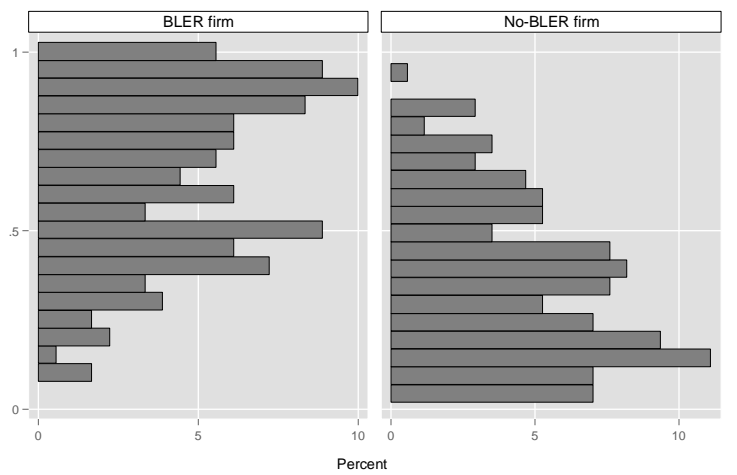

Note: Distribution of predicted BLER status for BLER and No-BLER firms.

Panel B: Prediction based on determinants regression, Specification II

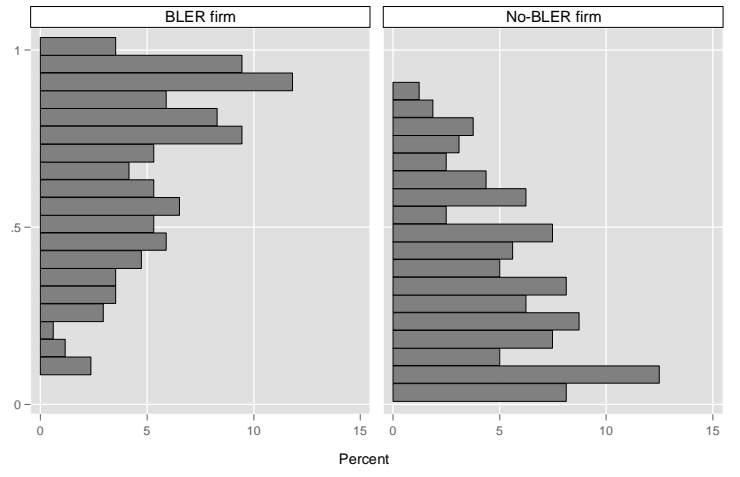

Note: Distribution of predicted BLER status for BLER and No-BLER firms.

Panel C: Prediction based on determinants regression, Specification III

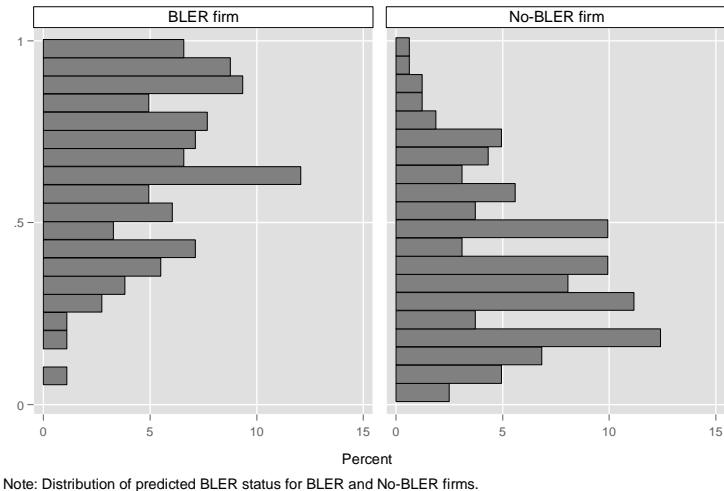

Note: Distribution of predicted BLER status for BLER and No-BLER firms.

Notes: The figure illustrates predicted BLER probabilities for BLER and Non-BLER firms based on probit regressions as reported in Table 4. 
In addition to the cross-sectional analysis tabulated in Table 4, we inspect the causes behind eventual changes in employee representation across the years. For this purpose, we extend our baseline sample period and collect selected board and firm-level information for an additional period between 2000-2003, thereby looking at precrisis period spreading over 2000-2007. With this empirical test we primarily want to exclude the possibility that the implementation of BLER is driven by the workers' anticipation of employment reductions. As first evidence against this, we observe that more than 90 percent of the firms in our sample have had BLER since the year 2000. We next estimate a firm-fixed-effects regression using the dummy for employee representation or the percentage of employee directors on the board as the dependent variable, and different measures of firm performance and other firm characteristics as explanatory variables. We find that the few changes in BLER during 2000-2007 mostly associate with changes in firm size. No other firm characteristics, a variety of firm performance measures in particular, have any significant effect on either the installation or dissolution of BLER. ${ }^{17}$

\subsection{BLER and workforce reductions during the Great Recession}

Following the line of enquiry of our theoretical propositions, we next analyze whether the companies with employee directors on their boards (BLER firms) were less likely to experience reductions in employment in the wake of poorer performance during the Great Recession. Consequently, we estimate the following equation:

$$
\begin{gathered}
y=\beta_{1} \times \text { Crisis } \times B_{L E R_{2007} \times R O A+\beta_{2} \times \text { Crisis } \times B L E R_{2007}+\beta_{3} \times B L E R_{2007} \times R O A} \\
+\beta_{4} \times R O A+\beta_{5} \times B L E R_{2007}+\sum \beta_{j} \times X_{j}+\text { fixed effects }+\varepsilon
\end{gathered}
$$

where $y$ is our employment reduction measure, and $\beta_{1}$ is our key coefficient of interest and measures the difference in the performance-sensitivity of employment reduction between BLER and non-BLER firms during the Great Recession. In our baseline regression, we measure employment reductions by the variable $\Delta 5+$ Percent, i.e., a dummy variable indicating cases where, between $\mathrm{t}$ and $(\mathrm{t}+1)$, we observe a decrease of at least 5 percent in the number of employees. For robustness, we run our regressions twice more using alternative employment reduction 
measures, i.e., $\Delta 10+$ Percent and $\Delta$ (negative employment growth, not in percentage). Our key explanatory variables are: the dummy variable indicating those firms with at least one employee-elected member on their boards (BLER); the Crisis dummy that indicates the time period of the peak of the Great Recession in Europe (i.e., the years 2008 and $2009^{18}$ ); and firm performance (ROA, ROE, Sales' margin).

The set of control variables $\left(\mathrm{X}_{\mathrm{j}}\right)$ includes all observable characteristics that might, theoretically, affect employment, particularly the firms' propensity to reduce workforce, and that might also correlate with our BLER dummy, such as firm size, firm performance, tangibility of firm assets, research intensity, firm age and ownership structure. Besides the fact that firm size is positively correlated with BLER, we might expect large firms to be less likely to reduce employment during crisis, as these firms might have more alternative solutions at their disposal (i.e., reallocation within the organization or business group). Moreover, a 5 percent employment reduction implies a higher absolute number of jobs in large firms; more job reductions are in turn more likely to motivate public attention. In our regressions we also control for the assets' tangibility and research and development intensity. This is to acknowledge the possibility that human capital is more relevant in BLER firms; the relevance of human capital might also affect firms' propensity to reduce employment. We also control for leverage, as more indebted firms face more constraints and might consequently be forced to reduce employment. To the contrary, firms with more concentrated ownership might be less exposed to capital market pressure and, therefore, also less restrained in their employment decisions. We also expect that better-performing firms are less likely to reduce employment. Accordingly, we observe that, during the crisis period, the incidence of 5+ percent decreases in employment was about 20 percentage points higher among the sub-group of firms that experienced a fall in operating performance, compared to other firms (results not tabulated). Finally, we include firm age in all our specifications. Given the higher propensity of BLER implementation during the seventies, the firm age results as one of the key factors determining the presence of BLER; firm age might however also affect firms' propensity to reduce employment ${ }^{19}$.

We report the main results of the regression analyses in Table 5. The estimates reported in the table are based on 2004-2010 period, with the crisis years defined as 2008 and 2009. Our dependent variables for employment reductions measure the employment changes between $t$ and $(t+1)$; with the crisis effects we therefore capture employment changes during 2009 and 2010. As shown by Glasser et al. (2011), employment effects generally lag 
those in output during a recession and, although in the majority of the European countries output started to rise in 2010, the employment situation in most countries deteriorated in both 2009 and 2010. Adopting a forward-looking measure of employment reductions also reduces concerns with regards to using ROA (or, alternatively, ROE, Sales' margin) as a measure of performance at time t.

In Specifications (I) and (II) in Table 5, Panel A, we show the estimates of a basic linear probability model for the firms without employee board representation $(B L E R=0)$ and the firms with employee board representation $(B L E R=1)$. According to the coefficients tabulated in Table 5, a lower operating performance (ROA) in normal times associates with a higher likelihood of workforce reduction in both types of firms. During the crisis, however, the picture changes (see the coefficient for ROA $x$ Crisis); while performance-sensitivity remains unaffected in firms without BLER (BLER=0), it falls significantly in BLER firms. To test for the statistical significance of the observed differences, we pool both subsamples and, in Specifications (III) and (IV), include a triple interaction term (BLER $\times$ ROA $\times$ Crisis) and the corresponding double interaction terms. Specification (III) includes time-, industry- and country-fixed effects, while Specification (IV) includes time- and firm-fixed effects. Confirming what was observed in Specifications (I) and (II), the triple-interaction term is positive and significant in both specifications. This suggests that, during the Great Recession, the performance-sensitivity of employment was significantly lower in BLER firms but not in other firms. Based on the size of the coefficients, we can conclude that, during the crisis, firm performance had no effect on workforce reductions in BLER firms $(\mathrm{F}=0.62$; Prob > $0.43)^{20}$.

To validate these results, we re-estimate Specifications (III) and (IV) using the alternative definitions of employment reductions defined earlier, namely $\Delta 10+$ Percent and $\Delta$ as negative employment growth. Results of this exercise are reported in in Panel B of Table 5. Similar to those shown in Panel A, the results reported in Panel B suggest a significant reduction in the employment-performance sensitivity for BLER firms during the crisis but not for other firms. 
Table 5: Employment reduction regression

\begin{tabular}{|c|c|c|c|c|}
\hline \multirow{4}{*}{$\begin{array}{l}\text { Dependent variable } \\
\text { Method } \\
\text { Sample } \\
\text { Specification }\end{array}$} & \multicolumn{4}{|c|}{$\Delta 5+$ Percent } \\
\hline & \multirow{3}{*}{$\begin{array}{c}\text { BLER=0 } \\
\text { I }\end{array}$} & \multirow{3}{*}{$\begin{array}{c}\text { OLS } \\
\text { BLER=1 } \\
\text { II }\end{array}$} & \multirow{2}{*}{\multicolumn{2}{|c|}{$\begin{array}{l}\text { Fixed effects } \\
\text { All firms }\end{array}$}} \\
\hline & & & & \\
\hline & & & III & IV \\
\hline \multirow[t]{2}{*}{ ROA } & $-0.004^{* * *}$ & $-0.006^{* * *}$ & $-0.003^{\star \star *}$ & $-0.004^{\star *}$ \\
\hline & {$[-3.69]$} & [-3.97] & {$[-3.67]$} & {$[-2.43]$} \\
\hline \multirow{2}{*}{ ROAxCrisis } & -0.002 & $0.005^{\star \star}$ & -0.002 & 0.000 \\
\hline & {$[-1.26]$} & [2.31] & {$[-1.35]$} & {$[-0.31]$} \\
\hline \multirow[t]{2}{*}{ BLERxROAxCrisis } & & & $0.007^{\star \star \star}$ & $0.007^{\star \star}$ \\
\hline & & & [2.65] & {$[2.30]$} \\
\hline \multirow[t]{2}{*}{ BLERxCrisis } & & & -0.053 & -0.054 \\
\hline & & & {$[-1.07]$} & {$[-1.00]$} \\
\hline \multirow[t]{2}{*}{ BLER } & & & 0.052 & \\
\hline & & & {$[1.60]$} & \\
\hline \multirow[t]{2}{*}{ BLERxROA } & & & -0.003 & -0.003 \\
\hline & & & {$[-1.64]$} & {$[-1.01]$} \\
\hline \multirow[t]{2}{*}{ Size } & 0.020 & $-0.025^{\star *}$ & -0.008 & $0.089^{*}$ \\
\hline & [1.53] & {$[-2.00]$} & {$[-0.88]$} & {$[1.86]$} \\
\hline \multirow[t]{2}{*}{ Tangibility } & 0.000 & 0.000 & 0.001 & -0.001 \\
\hline & {$[0.14]$} & {$[0.25]$} & {$[0.66]$} & {$[-0.58]$} \\
\hline \multirow[t]{2}{*}{$\mathrm{RnD}$} & -0.001 & 0.000 & -0.002 & 0.004 \\
\hline & {$[-0.57]$} & {$[-0.15]$} & {$[-0.97]$} & [1.03] \\
\hline \multirow[t]{2}{*}{ Leverage } & 0.001 & $0.002^{*}$ & $0.001^{*}$ & $0.003^{\star *}$ \\
\hline & {$[0.73]$} & [1.82] & [1.79] & [2.12] \\
\hline \multirow[t]{2}{*}{ Age $(\operatorname{In})$} & -0.027 & 0.003 & -0.010 & 0.289 \\
\hline & {$[-0.86]$} & [0.12] & {$[-0.53]$} & [1.49] \\
\hline \multirow[t]{2}{*}{ Block } & 0.000 & 0.000 & 0.000 & $-0.003^{* *}$ \\
\hline & {$[-0.48]$} & {$[-0.26]$} & {$[-0.61]$} & {$[-2.34]$} \\
\hline Firm effects & no & no & no & yes \\
\hline Industry and country effects & yes & yes & yes & no \\
\hline Observations & 699 & 901 & 1,600 & 1,600 \\
\hline Adj. $R^{\wedge} 2$ & 0.11 & 0.13 & 0.11 & 0.13 \\
\hline
\end{tabular}

Panel B: Alternative measures of employment reduction

\begin{tabular}{|c|c|c|c|c|}
\hline \multirow{3}{*}{$\begin{array}{l}\text { Dependent variable } \\
\text { Method } \\
\text { Sample }\end{array}$} & \multicolumn{2}{|c|}{$\Delta 10+$ Percent } & \multicolumn{2}{|c|}{$\Delta$} \\
\hline & OLS & Fixed effects & OLS & Fixed effects \\
\hline & \multicolumn{4}{|c|}{ All firms } \\
\hline Specification & v & VI & VII & VIII \\
\hline \multirow[t]{2}{*}{ BLERxROAxCrisis } & $0.005^{\star \star}$ & $0.005^{\star \star}$ & $0.002^{*}$ & $0.002^{*}$ \\
\hline & {$[2.40]$} & {$[2.04]$} & [1.73] & [1.70] \\
\hline Other controls & yes & yes & yes & yes \\
\hline Firm effects & no & yes & no & yes \\
\hline Industry and country effects & yes & no & yes & no \\
\hline Observations & 1,600 & 1,600 & 1,600 & 1,600 \\
\hline Adj. $R^{\wedge} 2$ & 0.07 & 0.07 & 0.06 & 0.06 \\
\hline
\end{tabular}

Notes: This table reports panel data regressions that examine the performance sensitivity of firms' employment reductions during the crisis, controlling for firm and governance characteristics. All models include also year effects. Panel A explains a dummy variable, $\Delta 5+$ Percent, indicating employment reductions of at least 5 percent of the firms' employees. Panel B reports results for alternative employment reduction measures. Specification I (II) is estimated on the subsample of BLER firms (non-BLER firms), all others on the aggregate sample. Moreover, while Specifications IIII, V, and VII include year-, country- and industry-fixed effects, Specifications IV, VI, and VIII include firm- and year-fixed effects. The sample period is 2004-2010. All variables are described in detail in Table 1. Numbers in brackets are t-values robust to heteroscedasticity and residuals clustering at the firm level.

Significance levels: ${ }^{*} \mathrm{p}<0.10,{ }^{* *} \mathrm{p}<0.05, * * * \mathrm{p}<0.01$ 
We perform additional robustness checks. First, in Table 5A we replicate the key estimates based on alternative measures of firm performance, namely the Sales' margin (EBIT to revenues, measured as a percentage) in panel $\mathrm{A}$, and Return on equity $(\mathrm{ROE}=$ net income to equity, measured as a percentage) in panel $\mathrm{B}$. Before the crisis, the employment reductions in BLER firms are more strongly linked to firm performance, measured either by Sales' margin or ROE. For these firms only, however, this sensitivity is then significantly reduced during the Great Recession; for non-BLER firms and the sales margin measure, we however observe an increased employment-to-performance sensitivity during the Great Recession. This evidence overall corroborates the results reported in Table 5. 
Table 5A: Employment reductions with alternative performance measures

Panel A: Employment reductions larger than 5 percent (Sales margin)

\begin{tabular}{|c|c|c|c|c|}
\hline \multirow{4}{*}{$\begin{array}{l}\text { Dependent variable } \\
\text { Method } \\
\text { Sample } \\
\text { Specification }\end{array}$} & \multicolumn{4}{|c|}{$\Delta 5+$ Percent } \\
\hline & \multirow{3}{*}{$\begin{array}{c}\text { BLER=0 } \\
\text { A.I }\end{array}$} & \multirow{3}{*}{$\begin{array}{c}\text { OLS } \\
\text { BLER=1 } \\
\text { A.II }\end{array}$} & & \multirow{2}{*}{ Fixed effects } \\
\hline & & & & \\
\hline & & & A.III & A.IV \\
\hline \multirow[t]{2}{*}{ SalesMargin } & 0.000 & $-0.007^{\star \star}$ & $0.000^{* *}$ & 0.000 \\
\hline & {$[1.27]$} & {$[-2.46]$} & {$[2.40]$} & {$[0.54]$} \\
\hline \multirow[t]{2}{*}{ SalesMarginxCrisis } & $-0.002^{\star \star \star}$ & $0.023^{\star \star \star}$ & $-0.003^{* * *}$ & $-0.002^{\star \star \star}$ \\
\hline & {$[-4.49]$} & [7.40] & {$[-4.58]$} & {$[-3.26]$} \\
\hline \multirow[t]{2}{*}{ BLERxSalesMarginxCrisis } & & & $0.028^{\star \star \star}$ & $0.027^{\star \star \star}$ \\
\hline & & & [10.36] & [8.12] \\
\hline \multirow{2}{*}{ BLERxCrisis } & & & -0.019 & -0.016 \\
\hline & & & {$[-0.39]$} & {$[-0.32]$} \\
\hline \multirow[t]{2}{*}{ BLER } & & & 0.034 & \\
\hline & & & {$[1.08]$} & \\
\hline \multirow{2}{*}{ BLERxSalesMargin } & & & $-0.005^{*}$ & -0.002 \\
\hline & & & {$[-1.92]$} & {$[-0.48]$} \\
\hline Other controls & yes & yes & yes & yes \\
\hline Firm effects & no & no & no & yes \\
\hline Industry and country effects & yes & yes & yes & no \\
\hline Year effects & yes & yes & yes & yes \\
\hline Observations & 691 & 899 & 1.590 & 1.590 \\
\hline Adj. $R^{\wedge} 2$ & 0.09 & 0.12 & 0.10 & 0.12 \\
\hline \multicolumn{5}{|c|}{ Panel B: Employment reductions larger than 5 percent (ROE) } \\
\hline \multicolumn{2}{|l|}{ Dependent variable } & \multicolumn{2}{|c|}{$\Delta 5+$ Percent } & \\
\hline \multicolumn{2}{|l|}{ Method } & \multicolumn{2}{|l|}{ OLS } & Fixed effects \\
\hline \multirow{2}{*}{$\begin{array}{l}\text { Sample } \\
\text { Specification }\end{array}$} & BLER=0 & BLER=1 & \multicolumn{2}{|c|}{ All firms } \\
\hline & B.I & B.II & B.III & B:IV \\
\hline \multirow[t]{2}{*}{ ROE } & 0.000 & $-0.002^{\star * *}$ & 0.000 & 0.000 \\
\hline & {$[-0.81]$} & {$[-3.38]$} & {$[-0.96]$} & {$[-0.21]$} \\
\hline \multirow[t]{2}{*}{ ROExCrisis } & 0.000 & $0.002^{\star \star *}$ & 0.000 & 0.000 \\
\hline & {$[0.60]$} & [2.70] & {$[0.48]$} & {$[0.37]$} \\
\hline \multirow[t]{2}{*}{ BLERxROExCrisis } & & & 0.001 & $0.002^{*}$ \\
\hline & & & [1.64] & [1.93] \\
\hline \multirow[t]{2}{*}{ BLERxROE } & & & $-0.001^{\star *}$ & $-0.002^{\star *}$ \\
\hline & & & {$[-2.00]$} & {$[-2.37]$} \\
\hline Other controls & yes & yes & yes & yes \\
\hline Firm effects & no & no & no & yes \\
\hline Industry and country effects & yes & yes & yes & no \\
\hline Year effects & yes & yes & yes & yes \\
\hline Observations & 699 & 902 & 1.601 & 1.601 \\
\hline Adj. $R^{\wedge} 2$ & 0.08 & 0.12 & 0.09 & 0.12 \\
\hline
\end{tabular}

Notes: This table reports panel data regressions that re-examine the performance sensitivity analysis from Table 5-Panel A using alternative performance measures. As in Table 5-Panel A, the dependent variable is a dummy variable, $\Delta 5+$ Percent, indicating employment reductions of at least 5 percent of the firms' employees. Performance is proxied by sales margin (Panel A) and by return on equity (Panel B), measured as percentage. Specification A/B.I (A/B.II) is estimated on the subsample of BLER firms (Non-BLER firms), all others on the aggregate sample. Moreover, while Specifications A/B.I-A/B.III include year-, country- and industry-fixed effects, Specification IV includes firm- and year-fixed effects. The sample period is 20042010. All variables are described in detail in Table 1 . Numbers in brackets are $\mathrm{t}$-values robust to heteroscedasticity and residuals clustering at the firm level.

Significance levels: ${ }^{*} \mathrm{p}<0.10, * * \mathrm{p}<0.05,{ }^{* * *} \mathrm{p}<0.01$. 
Second, we challenge our estimation methods. In Table 5 and Table 5A we use an ordinary least squares (OLS) estimator, i.e. estimate a linear probability model (LPM). We choose the LPM rather than a probit model for consistency between the main result and the robustness checks (i.e., the specifications using negative employment growth $\Delta$ as the dependent variable) and for the sake of an easier interpretation of interaction terms (Ai and Norton, 2003). However, in untabulated robustness test, we carefully re-estimated our regressions using the Logit and Logit FE estimator (for $45+$ Percent changes) and the Tobit estimator (for negative employment growth $\Delta$ ). The results are consistent with what reported in Table 5. Moreover, to ensure reliability of our statistical inferences, and to control for heteroscedasticity and within-firm correlation of standard errors, we allow standard errors to cluster on the firm level in all the specifications. Alternatively, we estimated our regressions using Driscoll-Kraay standard errors that control for heteroscedasticity and serial correlation. The results (not tabulated) are robust to using Driscoll-Kraay covariance matrix with lags between 2 and 6.

Third, we address the unobserved heterogeneity problem. In Table 5 we control for a range of firm characteristics that vary over time and, in some of our specifications, include firm-fixed effects. Moreover, we define our variable BLER as of 2007. This should limit reverse-causality issues as the Great Recession was unanticipated by most observers, meaning that crisis expectations should not have influenced the distribution of BLER across the firms before the crisis (Lins et al., 2013). Yet, as our identification strategy builds on the cross-sectional distribution of employee representation, some concerns remain. We therefore undertake additional steps to validate our results. In a first step, we replicate our analyses from Table 5 using a matched sample approach. More specifically, we create a matched sample based on a propensity score matching approach using Stata's psmatch2 calling a 1:2 nearest neighbor matching of BLER firms vs non-BLER firms with replacement based on the set of covariates for 2007 as used in the determinants regression Table 4, Specification III. Before running the regressions, we carefully check the quality of the matching process which matches 120 treated with 160 untreated firms (49 treated firms could not be matched by psmatch2 because they violate the "common support assumption" 21 ) in (i) univariate analyses (the matching significantly reduces the biases along the covariates; no t-test indicates significant differences in the matched sample) and (ii) in multivariate analyses (the set of covariates in uninformative within the matched sample). The regression results, which are reported in the appendix, corroborate our baseline results from 
Table 5. Also, our results remain robust to variations when we use only a subset of covariates (Size, ROA, Leverage, industry, and country) or kernel matching approaches. Furthermore, we create a second matched sample using the coarsened exact matching procedure (CEM). Thereby, we match each BLER firm to a firm without BLER that is comparable to the former firm in terms of location (i.e., they are in the same country), industry characteristics (i.e., percentage of firms with BLER in the industry), size (i.e. they are comparable in terms of total assets), ROA and age. We then re-estimate our regressions on the sample of treated units for which matches could be identified, and their matches. The untabulated results again confirm our initial results from Table 5.

In a second step, we create a "horse race" between the employee representation dummy $(B L E R)$ and some other firm characteristics that relate to BLER and that might also, theoretically, explain the reduced performancesensitivity of employment during the crisis, such as family control, ownership concentration, regional characteristics, firm size and union density ${ }^{22}$. The results of these tests, all of them including time- and firm-fixed effects, are reported in Table 6. In Specifications (I) and (II), Table 6, we check whether BLER is capturing the effect of family or other long-term owners as these might be more concerned about employees (employment), regardless of whether employees are represented on the board or not. To control for this, we include triple interaction term Family $x$ ROA $x$ Crisis in Specification (I) and Block $x$ ROA $x$ Crisis in Specification (II), as well as the corresponding double interaction terms (the coefficients for the latter are not tabulated for the sake of space). In Specification (III), we allow for the possibility that the BLER is capturing regional effects, thereby including a triple interaction term (Capital Location $x$ ROA $x$ Crisis). Along similar lines, we address size effects and in Specification (IV) include a triple interaction term including the dummy Large Firm, which identifies firms employing at least 250 employees (Large Firm $\times$ ROA $\times$ Crisis). None of the added triple interaction terms turns out to be significant, nor does including them alter the coefficients of the main variable of interest. 
Table 6: Employment reduction regression with additional interaction terms

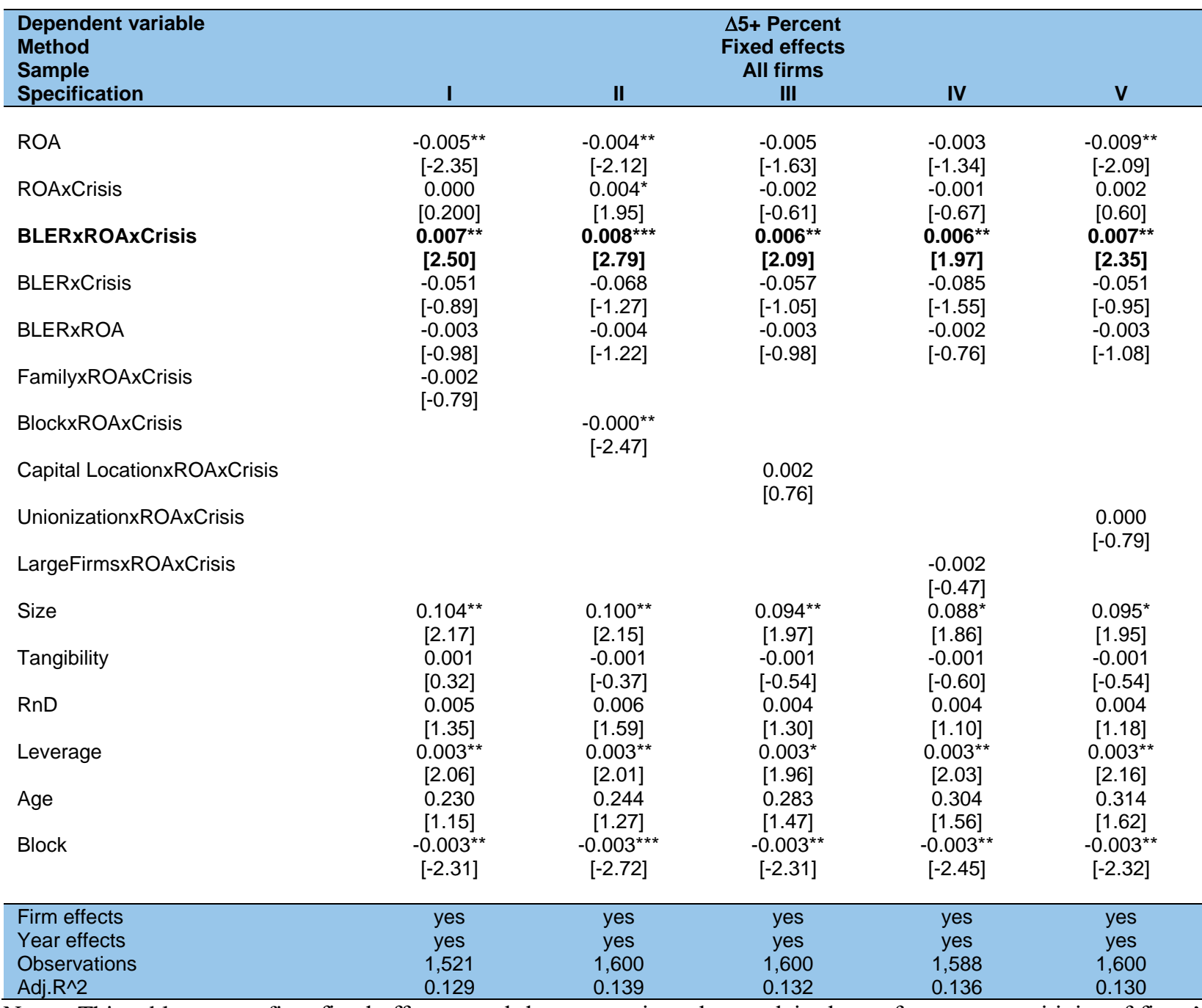

Notes: This table reports firm-fixed effects panel data regressions that explain the performance sensitivity of firms' employment reductions during the crisis, similar to the previously reported Specification IV Table 5-Panel A, but controlling for characteristics correlated with BLER status. The sample period is 2004-2010. Base effects and double interaction terms are not reported for the sake of space. All variables are described in detail in Table 1. Numbers in brackets are t-values robust to heteroscedasticity and residuals clustering at the firm level.

Significance levels: ${ }^{*} \mathrm{p}<0.10,{ }^{* *} \mathrm{p}<0.05, * * * \mathrm{p}<0.01$. 
Finally, in Specification (V), Table 6, we give some more attention to the relationship between labor unions and employee board representation, and its implications for the results presented above. Economists have long debated the unions' preference set and the relative weighting that the unions give to wages and employment within this set. In this regard, three different models of union behavior have been proposed in the literature, namely i) the Monopoly Union Model, in which unions unilaterally set wages and employers adjust the employment accordingly, ii) the Right-to-Manage Model, in which unions and employers bargain over the wages and employers then set the employment unilaterally, and iii) the Efficient Bargaining Model, which assumes that unions and employers bargain over the wages and employment, thereby allowing for the emergence of cooperative outcomes in unionemployer bargaining (Gahan, 2002). The latter two models have found support in the empirical literature, with more recent evidence suggesting that unions might become involved in efficient bargaining when facing the probability of employment reductions in hard economic times (Gahan, 2002; Lawson, 2011). At the same time, union density might be positively related to the presence of BLER; although we find no significant relationship in our sample, a positive correlation between union density and BLER finds some support in the literature (Gregorič and Poulsen, 2018). Therefore, further checks are necessary to demonstrate that BLER is not simply a proxy for stronger union density in the BLER firms.

To address this, in Specification (V), Table 6, we include the triple interaction term for union density (Unionization $\times$ ROA $\times$ Crisis). As shown in the table, this triple interaction term in the employment reduction specifications is neither statistically significant, nor alters the significance or size of our key coefficient of interest (BLER $\times$ ROA $\times$ Crisis). This result is not particularly surprising, at least for two reasons. First, the union density is overall very high in Scandinavia, at 69.5 percent in Denmark, 44 percent in Norway and 64 percent in Sweden, on average. The low variation in union density across the sectors of the firms in our sample might also explain the insignificant coefficient for Unionization reported in Table 4. Second, as argued above, while during the Great Recession the unions presumably played a strong role in negotiating sectoral and central agreements that facilitated and directed plant-level adjustments, the latter ultimately fell within the domain and thus depended on the actions of the local actors, often those at higher organizational levels, such as the board of directors ${ }^{23}$. 


\subsection{Board-level employee representation (BLER) and labor-cost adjustments as an alternative to em- ployment reductions}

In the previous section we established that BLER firms were associated with a significantly lower sensitivity of employment reductions to firm performance during the Great Recession. Based on the minority representation of employees on the board of directors, concentrated corporate ownership, the tradition of Scandinavian system of board representation, and the insights from the theoretical literature, we attributed this effect to employee directors' ability to facilitate the employee-employer negotiations of cooperative adjustments to the crisis, thereby contributing to the adoption of solutions that provided employment security in exchange for workers' concessions in the form of reduced work-time and other measures of labor-costs savings. Anecdotal and case evidence from Scandinavia similarly point to the fact that the higher job security in specific firms during the crisis might have been ensured by measures of labor-costs savings that are alternative to employment cuts, such as temporary absences, work-sharing agreements, and employee wage concessions. While we cannot observe these measures directly, it is reasonable to assume that these different measures all lead to a reduction of the total labor costs at the given level of employment (i.e., lower labor cost per employee).

Accordingly, we next test whether in BLER firms lower employment reduction, i.e. excess employment, associates with stronger downward adjustments of labor cost during the crisis. Therefore, we regress the relative change in a firm's labor costs per employee (measured in percent) on a measure of excess employment in the firm. Since we are interested in the trade-off between labor costs and excess employment within BLER firms during the crisis, we estimate these regressions on the subsample of BLER firms (only) during 2008-2009.

A key ingredient for this analysis is a measure of excess employment. We construct such a measure in three steps. First, we estimate three versions of the regression from specification I, Tabel 5, Panel A: (i) an OLS regression using negative employment growth $\Delta$ as the dependent variable, and probit regressions using (ii) $\Delta 5+$ Percent and (iii) $410+$ Percent as the dependent variable. In all three cases, we restrict the sample to non-BLER firms and the 2008-2009 period. The results of these regressions are reported in Appendix.Table 2. Second, we use the estimated coefficients from these estimations to form predictions about what the ceteris paribus workforce reductions might have been in BLER firms, if they had behaved as non-BLER firms during the crisis period. Third, 
based on the predictions from the estimation (i) with negative employment growth, we first define the variable ExcessEmployment; the variable captures the difference between the estimated employment reductions that BLER firms might be assumed to have implemented if they had behaved as comparable non-BLER firms did during the crisis, and the actual employment reductions in BLER firms. As such, a higher value of ExcessEmployment means that, ceteris paribus, the BLER firm has lower employment reductions and thus higher employment than its nonBLER peer. Alternatively, based on the the predictions from the estimation (ii) and (iii), we define the variables (ExcessEmployment(5 perc) and ExcessEmployment(10 perc), capturing the differences in the firms' propensity to reduce employments by 5 or 10 percent, respectively.

In Table 7, we inspect differences in ExcessEmployment within the sub-sample of BLER firms by regressing the size of ExcessEmployment on a number of characteristics of the BLER firms. For the sake of presentation, we measure ExcessEmployment as a percentage here, i.e. ExcessEmployment (in \%). 
Table 7: Excess employment: First inspection

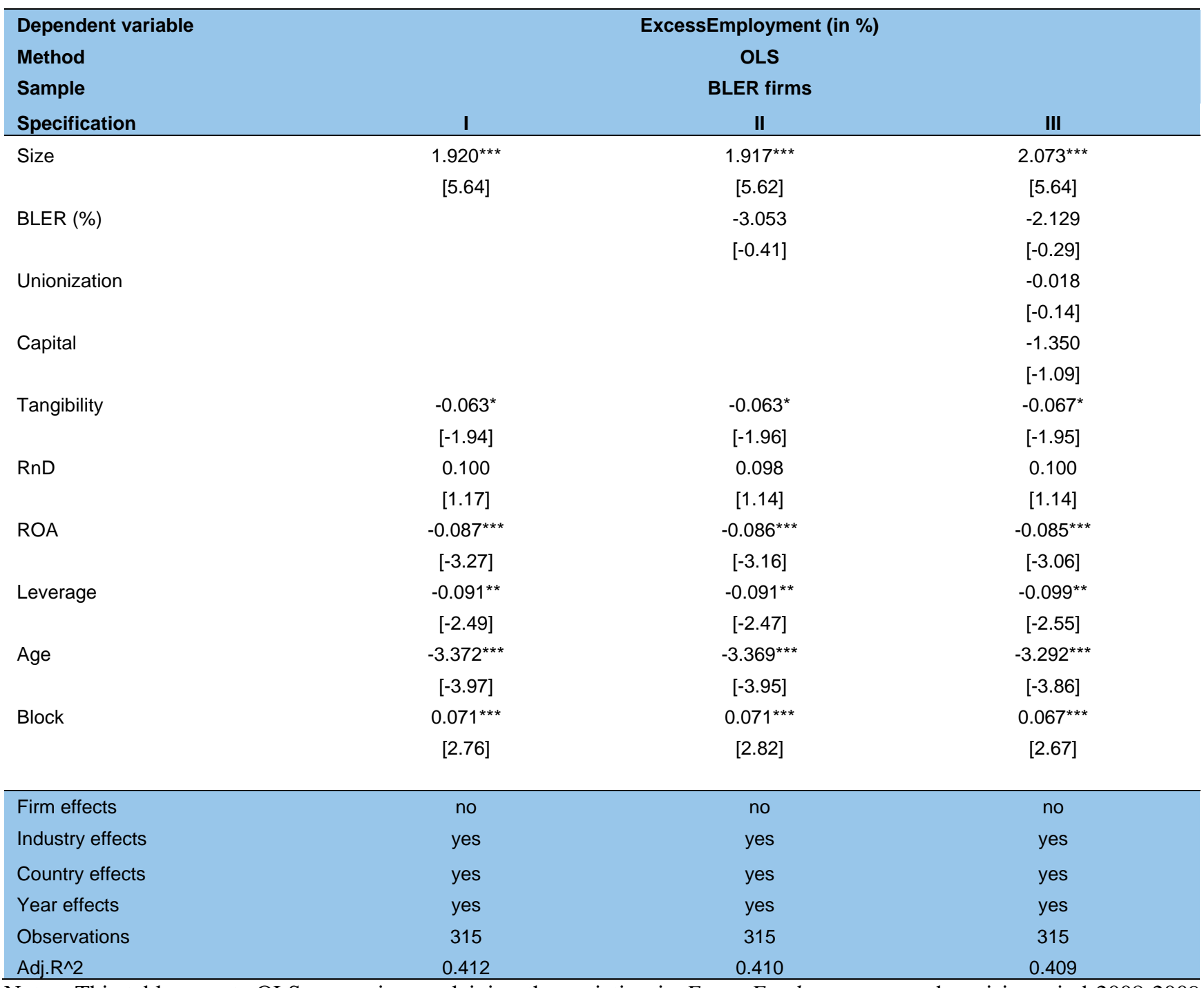

Notes: This table reports OLS regression explaining the variation in ExcessEmployment over the crisis period 2008-2009 within BLER firms. For the sake of coefficient representation, we express ExcessEmployment, in this table only, as a percentage. Thereby, ExcessEmployment is the abnormal employment of a BLER firm, as a percentage, relative to a ceteris paribus non-BLER firm derived in three steps. First, we use firm and governance characteristics as well as year-, industry, and country-fixed effects to explain the employment reduction decisions of non-BLER firms during the crisis, where the latter are measured by the employment reduction variables $\Delta$ (This regression is tabulated in Table Appendix.2). Second, we use the coefficients of these first-stage regressions and apply them to BLER firms to predict the expected employment reduction. Third, we define ExcessEmployment as the difference between the expected employment reduction and the actual employment reduction, and state it in percentage terms. All explanatory variables are described in detail in Table 1. Numbers in brackets are $\mathrm{t}$-values robust to heteroscedasticity and residuals clustering at the firm level.

Significance levels: $* \mathrm{p}<0.10, * * \mathrm{p}<0.05, * * * \mathrm{p}<0.01$ 
The table provides a number of interesting insights. First, as one might expect, ExcessEmployment is negatively correlated with the BLER firm's operating performance: The worse the performance of the BLER firm, the higher the excess employment in the firm. Moreover, Excess Employment is positively correlated with firm size, which is in line with a view suggesting that larger firms have more flexibility to reallocate potentially redundant employees. In terms of the relationship between ExcessEmployment and the other variables in the regression, we could argue that they are in line with the employers' willingness to enter into cooperative agreements in the BLER firms. Specifically, ExcessEmployment is higher in the BLER firms with lower levels of tangible assets; the value of human capital is higher in these firms, which should also make employers' more inclined to negotiate cooperative agreements with the employees in the BLER firms. The companies with more concentrated ownership and, consequently, more long-term oriented owners, might be also more inclined to enter into cooperative agreements with the employees, while the opposite might hold for more highly leveraged firms; both finds support in Table 7. Finally, the size of ExcessEmployment in BLER firms does not vary with the percentage of employee directors on board and also not with industry-level union density (Unionization). The former result is in line with the basic proposition of this study with regards to the power of BLER in Scandinavian firms; we argued that, while the \% of employee directors might vary across firms, in most cases workers hold about a third of board seats and they are never in majority (by law), meaning that the observed variations in the share of employee directors likely imply no significant differences in terms of workers' ability to direct board decisions. The insignificant impact of the union density (Unionization) corroborates our previous conclusions about the limited role of unions on firm-level agreements during the crisis.

In the next step, we now regress the relative changes in labor costs per employee (in percent) on our measures of excess employment for the subsample of BLER firms during years 2008-2009. Results of this analysis are reported in Table 8. 
Table 8: Employment reduction and labor cost adjustments during the crisis

\begin{tabular}{|c|c|c|c|c|c|}
\hline \multirow{3}{*}{$\begin{array}{l}\text { Dependent variable } \\
\text { Method } \\
\text { Sample } \\
\text { Specification }\end{array}$} & \multicolumn{5}{|c|}{$\begin{array}{l}\text { Relative change in labor costs per employee (\%) } \\
\text { OLS }\end{array}$} \\
\hline & \multirow{2}{*}{$\begin{array}{c}\text { BLER firms only } \\
\text { I }\end{array}$} & \multirow{2}{*}{$\begin{array}{l}\text { BLER firms in in- } \\
\text { dustries with low } \\
\text { level of unioniza- } \\
\text { tion } \\
\text { II.a }\end{array}$} & \multirow{2}{*}{$\begin{array}{l}\text { BLER firms in in- } \\
\text { dustries with high } \\
\text { level of unioniza- } \\
\text { tion } \\
\text { II.b }\end{array}$} & \multicolumn{2}{|c|}{ BLER firms only } \\
\hline & & & & III & IV \\
\hline ExcessEmployment & $\begin{array}{l}-60.504^{* * *} \\
{[-2.85]}\end{array}$ & $\begin{array}{l}-135.325^{\star \star \star} \\
{[-2.89]}\end{array}$ & $\begin{array}{c}-33.838^{* *} \\
{[-2.35]}\end{array}$ & & \\
\hline $\begin{array}{l}\text { ExcessEmployment } \\
\text { (5 perc) }\end{array}$ & & & & $\begin{array}{c}-8.803^{* * *} \\
{[-3.12]}\end{array}$ & \\
\hline $\begin{array}{l}\text { ExcessEmployment } \\
\text { (10 perc) }\end{array}$ & & & & & $-7.382^{* *}$ \\
\hline ROA & $\begin{array}{l}0.095^{\star} \\
{[1.78]}\end{array}$ & $\begin{array}{l}0.017 \\
{[0.18]}\end{array}$ & $\begin{array}{l}0.045 \\
{[0.57]}\end{array}$ & $\begin{array}{c}0.141^{\star *} \\
{[2.31]}\end{array}$ & $\begin{array}{c}{[-2.11]} \\
0.137^{\star *} \\
{[2.24]}\end{array}$ \\
\hline Size & $\begin{array}{l}0.567 \\
{[0.89]}\end{array}$ & $\begin{array}{l}1.370 \\
{[0.83]}\end{array}$ & $\begin{array}{l}0.795 \\
{[1.08]}\end{array}$ & $\begin{array}{l}0.009 \\
{[0.01]}\end{array}$ & $\begin{array}{l}0.188 \\
{[0.29]}\end{array}$ \\
\hline Tangibility & $\begin{array}{l}-0.035 \\
{[-0.60]}\end{array}$ & $\begin{array}{l}0.053 \\
{[0.49]}\end{array}$ & $\begin{array}{l}-0.098^{*} \\
{[-1.71]}\end{array}$ & $\begin{array}{l}0.004 \\
{[0.05]}\end{array}$ & $\begin{array}{l}0.028 \\
{[0.42]}\end{array}$ \\
\hline $\mathrm{RnD}$ & $\begin{array}{l}0.164 \\
{[1.23]}\end{array}$ & $\begin{array}{l}0.216 \\
{[0.99]}\end{array}$ & $\begin{array}{l}-0.102 \\
{[-0.35]}\end{array}$ & $\begin{array}{l}0.098 \\
{[0.53]}\end{array}$ & $\begin{array}{l}0.046 \\
{[0.23]}\end{array}$ \\
\hline Leverage & $\begin{array}{l}-0.061 \\
{[-1.21]}\end{array}$ & $\begin{array}{l}-0.074 \\
{[-0.71]}\end{array}$ & $\begin{array}{l}-0.029 \\
{[-0.48]}\end{array}$ & $\begin{array}{l}0.000 \\
{[0.01]}\end{array}$ & $\begin{array}{l}-0.026 \\
{[-0.47]}\end{array}$ \\
\hline InAge & $\begin{array}{l}-2.604^{* *} \\
{[-2.07]}\end{array}$ & $\begin{array}{l}-3.713 \\
{[-1.28]}\end{array}$ & $\begin{array}{c}-2.315^{\star *} \\
{[-2.01]}\end{array}$ & $\begin{array}{l}-1.875 \\
{[-1.39]}\end{array}$ & $\begin{array}{l}-2.284^{*} \\
{[-1.73]}\end{array}$ \\
\hline Block & $\begin{array}{l}0.006 \\
{[0.15]}\end{array}$ & $\begin{array}{l}0.015 \\
{[0.13]} \\
\end{array}$ & $\begin{array}{l}-0.031 \\
{[-0.70]} \\
\end{array}$ & $\begin{array}{l}-0.050 \\
{[-1.14]} \\
\end{array}$ & $\begin{array}{l}-0.017 \\
{[-0.41]}\end{array}$ \\
\hline Industry and country effects & yes & yes & yes & yes & yes \\
\hline Year effects & no & no & no & no & no \\
\hline Observations & 310 & 131 & 179 & 271 & 277 \\
\hline Adj. $R^{\wedge} 2$ & 0.321 & 0.406 & 0.270 & 0.298 & 0.278 \\
\hline
\end{tabular}

Notes: This table reports cross-sectional regressions that explain relative labor cost adjustments in BLER firms as a function of the firms' employment reduction decisions during the crisis. Thereby, ExcessEmployment is the abnormal employment of a BLER firm relative to a ceteris paribus non-BLER firm derived in three steps. First, we use firm and governance characteristics as well as year-, industry, and country-fixed effects to explain the employment reduction decisions of nonBLER firms, where the latter are measured by the employment reduction variables $\Delta, \Delta 5+$ Percent and $\Delta 10+$ Percent. (This regression is tabulated in Appendix.Table2). Second, we use the coefficients of these first-stage regressions and apply them to BLER firms to predict the expected employment reduction decision. Third, we define ExcessEmployment (ExcessEmployment(5 perc) and ExcessEmployment(10 perc)) as the difference between the expected employment reduction (expected propensity to reduce employment) and the actual employment reduction (actual propensity to reduce employment). All other variables are described in detail in Table 1. Numbers in brackets are t-values robust to heteroscedasticity and residuals clustering at the firm level.

Significance levels: ${ }^{*} \mathrm{p}<0.10, * * \mathrm{p}<0.05, * * * \mathrm{p}<0.01$. 
Examining all BLER firms, Specification I indicates that higher Excess Employment (i.e., lower employment reductions in BLER firms compared to non-BLER firms) associates negatively with the change in labor costs per employee during the Great Recession. Specifically, a one percent higher employment during crisis is compensated by a 0.6 percent decrease in labor costs per employee in the average BLER firm. ${ }^{24}$ This result suggests that, indeed, the higher employment in BLER firms during the crisis was in part secured by alternative means of reducing labor costs, resulting in a decrease in the labor costs per employee. These results are in line with Table 3 and our theoretical propositions.

Next, we divide the sample of BLER firms into those operating in industries with high and moderate to low levels of unionization, using the simple mean of sector-level union density provided in Andersen et al. (2014), and assuming an equal distribution of firms between sectors. Comparing the results of Specifications II.a and II.b indicates that the impact of employment on workers' earnings is higher (lower) in industries with moderate (high) levels of unionization. One explanation for the observed differences between the sub-groups might relate to higher bargaining power of labor in the sectors with high union concentration. In these sectors, sector-level agreements might have created some constraints on the amount of alternative wage costs' adjustments during crisis. While this explanation is in line with related evidence (Svalund et al., 2013), further research is necessary to verify this claim. We thus leave the analysis of the interaction between BLER and sector-level union agreements to future research.

Finally, we re-estimate Specifications I using alternative measures of excess employment, namely the difference in the firms' probability to reduce employment by more than 5 or 10 percent, respectively, i.e, $E x$ cessEmployment( 5 perc) and ExcessEmployment $(10 \text { perc })^{25}$. The reported results in Specification III and IV again confirm that the higher employment in BLER firms during the crisis was in part secured by alternative means of reducing labor costs, thereby allowing for the necessary adjustments in labor costs without significant decrease in employment.

\subsection{Board-level employee representation (BLER) and firm value during the Great Recession}

The results presented thus far suggest that, in Scandinavia, board-level employee representation (BLER) might have contributed to higher employment during the years of Great Recession. This, however, came at a cost: The 
excess employment of BLER firms was associated with larger downward adjustment of labor costs per employee, probably facilitated by jointly negotiated agreements providing ground for alternative reductions in labor costs (i.e., reduction in worker hours/work weeks; work-sharing; temporary furloughs, etc.) to the benefit of higher employment. In effect, one might argue, in line with the results found in our initial analysis in Table 3, that BLER and non-BLER firms were equally successful in approaching the challenge to adjust total labor costs in response to the Great Recession. However, the analysis presented in Table 3 was only a very indirect test, and could not rule out a relatively pessimistic view that employees might use their power to extract rents from the firm. Thus, it seems natural to ask for a more direct test, i.e. an analysis that examines the implications of BLER during the Great Recession from the perspective of the firms' shareholders. This analysis is particularly important, when it comes to examining the hypothesis that BLER can indeed facilitate the implementation of cooperative agreements between employees and employers.

To shed some light on this, we now turn to stock returns and compare stock returns of BLER firms with that of non-BLER firms during the Great recession. Specifically, we provide two complementary tests in this regard. In Figure 6 we first create a simple time-series plot comparing three investment strategies (each assuming a monthly rebalancing approach to isolate the analysis from tail returns): 1) Strategy A is a simple portfolio strategy investing in our 365 sample firms; 2) Strategy B is a portfolio strategy investing in the 193 sample firms with BLER and 3) Strategy C, which is a portfolio strategy investing in the 172 sample firms without board-level employee representation. An eye-ball inspection of the time-series plot shown in Figure 6 suggests that there is not much difference between the three strategies during the crises time. If any, then the Strategy $\mathrm{C}$ marginally outperforms before the crisis, while - in line with our theoretical arguments - the Strategy B performs marginally (but statistically insignificantly) better during the crisis. 


\section{Figure 6: Index development}

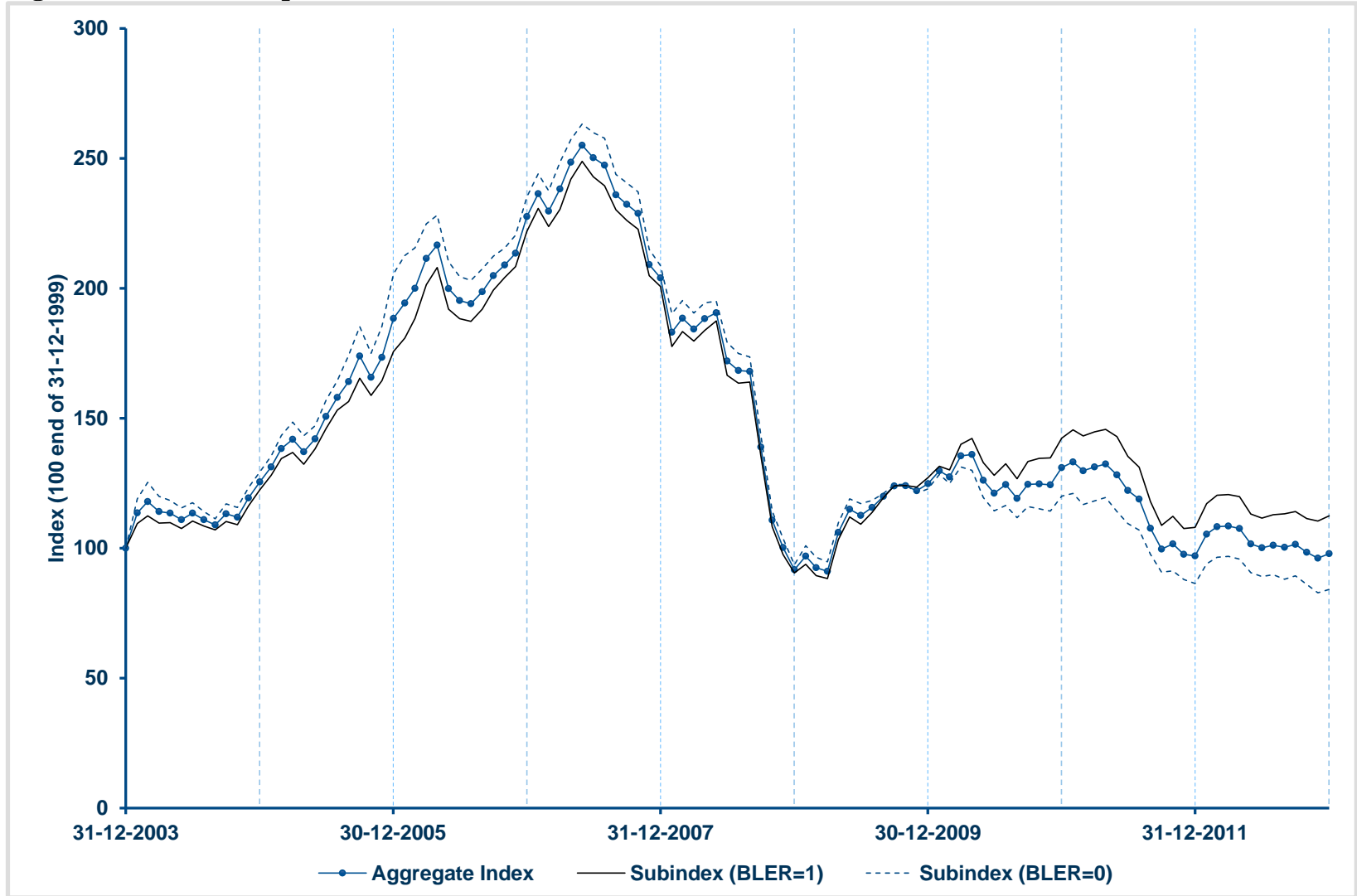

Notes: This figure illustrates the development of three stock price indices constructed based on our 365 sample firms. The Aggregate Index measures the price development of a monthly-rebalanced portfolio investing equally into each of our 365 stocks. The Subindex $(B L E R=1)$ (Subindex $(B L E R=0)$ ) measures the price development of a monthly-rebalanced portfolio investing equally into each of our BLER-stocks (Non-BLER stocks), where BLER status is determined in 2007. 
Second, we perform a set of cross-sectional regressions in the spirit of Lins et al. (2013), where we carefully account for the typical asset pricing risk factors (CAPM beta, Fama \& French (1993) Size and Value, and Carhart (1997) Momentum). The results, organized cross-sectionally and reported in Table 9, clearly demonstrate that BLER firms did not underperform during the Great Recession. Compared to non-BLER firms, the firms with employee board representation experienced either higher or similar stock returns during the crisis period. The coefficients measuring the differences in stock returns between BLER and non-BLER firms are positive, although the significance of the coefficients varies depending on the number of control variables included in the regression. All in all, the stock returns' behavior analysis suggests that, regardless of the above reported lower propensity to reduce employment, the presence of employee directors on board is not associated with any abnormal reduction in shareholder value during the Great Recession. This in turn suggests that the implemented solutions in BLER firms were either mutually beneficial for shareholders and employees or, at minimum, provided benefits to the employees without harming shareholders. These results corroborate the conclusion that, whatever measures the BLER firms undertook to secure employment during crisis, these measures most probably did not come at the expense of shareholder value. These results are in line with the cooperative nature of the employees-employer agreements hypothesized in the present study. 
Table 9: BLER and stock market returns during and after the Great Recession

\begin{tabular}{|c|c|c|c|c|c|c|c|c|c|c|c|c|c|}
\hline \multirow{2}{*}{ Model } & \multirow{2}{*}{ Dependent Variable } & \multirow{2}{*}{ Event window } & \multicolumn{2}{|c|}{ BLER } & \multicolumn{2}{|c|}{ Size } & \multicolumn{2}{|c|}{ Market-to-book } & \multicolumn{2}{|c|}{ Momentum (12m) } & \multirow{2}{*}{$\begin{array}{l}\text { Firm char- } \\
\text { acter-istics }\end{array}$} & \multirow{2}{*}{$\mathrm{N}$} & \multirow{2}{*}{ Adj. $R^{\wedge} 2$} \\
\hline & & & coeff & $p$-value & coeff & p-value & coeff & $p$-value & coeff & $p$-value & & & \\
\hline I.A & BAHR & 2007-2008 & 3.916 & {$[0.37]$} & & & & & & & no & 352 & 0.087 \\
\hline I.B.1 & risk-adjusted BAHR & $2007-2008$ & 3.182 & {$[0.25]$} & 8.698 & {$[0.19]$} & 0.425 & {$[0.28]$} & & & no & 344 & 0.016 \\
\hline I.B.2 & risk-adjusted BAHR & $2007-2008$ & $4.762^{* *}$ & {$[0.01]$} & 4.803 & {$[0.27]$} & 0.135 & {$[0.56]$} & $27.015^{\star}$ & {$[0.09]$} & no & 323 & 0.048 \\
\hline I.B.3 & risk-adjusted BAHR & $2007-2008$ & $7.334^{\star *}$ & {$[0.03]$} & 1.881 & {$[0.72]$} & -0.427 & {$[0.11]$} & 18.648 & {$[0.21]$} & yes & 323 & 0.107 \\
\hline II.A & BAHR & 2009-2010 & $21.165^{\star *}$ & {$[0.01]$} & & & & & & & no & 359 & 0.062 \\
\hline II.B.1 & risk-adjusted BAHR & $2009-2010$ & 3.564 & {$[0.65]$} & $8.583^{* *}$ & {$[0.03]$} & -0.12 & {$[0.61]$} & & & no & 357 & 0.089 \\
\hline II.B.2 & risk-adjusted BAHR & $2009-2010$ & 3.99 & {$[0.60]$} & $8.554^{* *}$ & {$[0.03]$} & -0.099 & {$[0.68]$} & -9.031 & {$[0.57]$} & no & 357 & 0.087 \\
\hline II.B.3 & risk-adjusted BAHR & $2009-2010$ & 8.026 & {$[0.42]$} & 1.819 & {$[0.55]$} & -0.443 & {$[0.53]$} & -15.903 & {$[0.64]$} & yes & 300 & 0.176 \\
\hline III.A & BAHR & 2009-2012 & 21.384 & {$[0.26]$} & & & & & & & no & 358 & 0.063 \\
\hline III.B.1 & risk-adjusted BAHR & 2009-2012 & 2.269 & [0.91] & $14.448^{* * *}$ & {$[0.00]$} & $-1.325^{\star}$ & {$[0.10]$} & & & no & 356 & 0.09 \\
\hline III.B.2 & risk-adjusted BAHR & 2009-2012 & 4.477 & [0.83] & $14.262^{* \star *}$ & {$[0.00]$} & -1.215 & {$[0.13]$} & -47.183 & {$[0.10]$} & no & 356 & 0.098 \\
\hline III.B.3 & risk-adjusted BAHR & 2009-2012 & 9.751 & {$[0.65]$} & 3.766 & {$[0.41]$} & -1.692 & {$[0.18]$} & -64.351 & {$[0.24]$} & yes & 299 & 0.188 \\
\hline
\end{tabular}

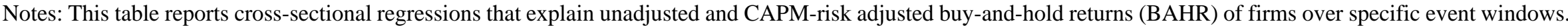

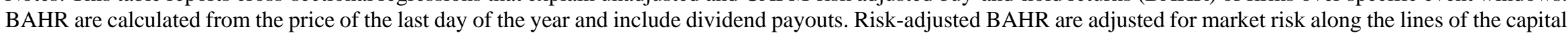

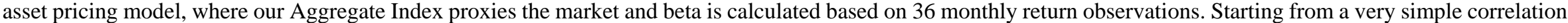

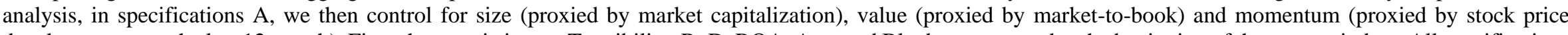

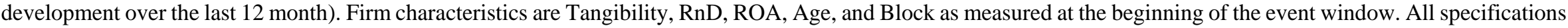
include industry and country effects. Numbers in brackets are p-values robust to heteroscedasticity and clustering of residuals at the country level.

Significance levels: $* \mathrm{p}<0.10, * * \mathrm{p}<0.05, * * * \mathrm{p}<0.01$. 
In this paper we argued that employee representatives on the board of directors are instrumental in the adoption of cooperative firm-level adjustment during a crisis. Using the shock of the Great Recession, and a longitudinal sample of Scandinavian firms, we find empirical support for these propositions. We have shown that the reported effects are robust across different specifications, samples and dependent variable specifications. The firms with BLER showed a significantly lower sensitivity of employment reductions to firm performance during the crisis; we showed that this lower sensitivity was partly ensured through downward adjustments in the labor costs per employee, presumably through flexible time agreements, reorganizations of bonus systems, temporary layoffs and work-sharing agreements. In support to the cooperative nature of the adopted solutions, we also find that, compared to non-BLER firms, the BLER firms experienced higher or, at least, no different stock returns during the Great Recession.

The reported results are in line with the overall idea of employee board representation in Scandinavia, where this mechanism of employee voice historically emerged as a contract between the employees and the shareholders for the purpose of aiding long-term competitiveness and firm growth. Accordingly, the employees in Scandinavian firms are granted a minority of board seats, and these seats can be filled only by those employed by the company or the business group to which it belongs. Thus, employees are probably more inclined to cooperate with rather than resist the shareholders, and this might hold both in good and bad economic periods. Considering these and other characteristics of Scandinavian economies (e.g., small open economies, relatively high unionization and unemployment subsidies), any generalization of our results to other countries, such as Germany, should be however made with caution. Regardless, our study provides novel evidence on the positive effects of employee board representation for firm decision-making, thereby complementing Fauver and Fuerst (2006), among others. While further research is necessary to corroborate this, our findings also indicate that more stakeholder-oriented governance may pay off in the case of global shocks, as was the case in the Great Recession. 


\section{Appendix}

Appendix.Figure 1: Frequencies of the estimated propensity score over groups

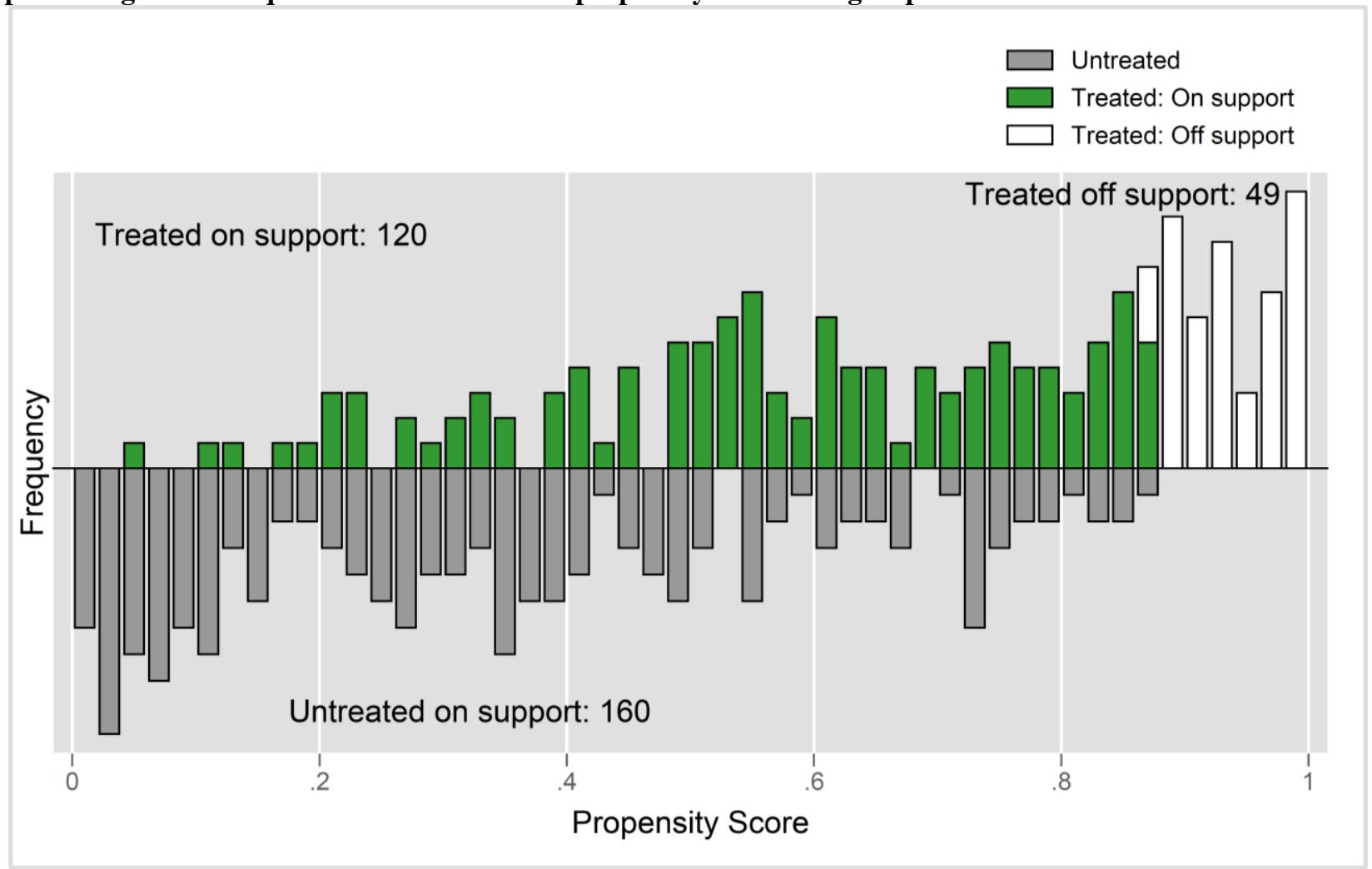

Notes: This figure illustrates frequencies of the estimated propensity score over groups (treated firms, i.e. BLER firms, vs. untreated firms, i.e. Non-BLER firms) using Stata's psgraph after psmatch2 calling a 1:2 nearest neighbor matching. Matching occurs in 2007 based on the set of covariates used in the determinants regression Table 4, Specification III. 
Appendix.Table 1: Employment reduction regression: Propensity Score Matching

\begin{tabular}{|c|c|c|c|c|c|}
\hline \multirow{4}{*}{$\begin{array}{l}\text { Dependent variable } \\
\text { Method } \\
\text { Sample } \\
\text { Specification }\end{array}$} & \multicolumn{3}{|c|}{$\Delta 5+$ Percent } & \multirow{3}{*}{$\begin{array}{c}\Delta \\
\text { Fixed effects }\end{array}$} & \multirow[t]{3}{*}{$\Delta 10+$ Percent } \\
\hline & Logit & OLS & & & \\
\hline & \multicolumn{3}{|c|}{ All firms } & & \\
\hline & I & II & III & IV & IV \\
\hline \multirow[t]{2}{*}{$\mathrm{ROA}$} & $-0.024^{\star \star \star}$ & $-0.003^{\star \star *}$ & $-0.004^{\star *}$ & -0.001 & $-0.003^{*}$ \\
\hline & {$[-3.81]$} & {$[-3.51]$} & {$[-2.03]$} & {$[-1.49]$} & {$[-1.73]$} \\
\hline \multirow[t]{2}{*}{ ROAxCrisis } & 0.000 & -0.001 & 0.000 & -0.001 & -0.002 \\
\hline & {$[0.04]$} & {$[-0.91]$} & {$[-0.09]$} & {$[-1.26]$} & {$[-1.06]$} \\
\hline \multirow[t]{2}{*}{ BLERxROAxCrisis } & $0.050^{\star * *}$ & $0.009^{\star * *}$ & $0.011^{* * *}$ & $0.004^{\star * \star}$ & $0.008^{\star \star *}$ \\
\hline & [3.60] & [3.78] & {$[3.90]$} & [3.32] & [3.18] \\
\hline \multirow[t]{2}{*}{ BLERxCrisis } & -0.252 & -0.040 & -0.060 & -0.019 & -0.035 \\
\hline & {$[-0.84]$} & {$[-0.70]$} & {$[-0.97]$} & {$[-1.20]$} & {$[-0.63]$} \\
\hline \multirow[t]{2}{*}{ BLER } & 0.310 & $0.058^{*}$ & & & \\
\hline & {$[1.40]$} & {$[1.70]$} & & & \\
\hline \multirow[t]{2}{*}{ BLERXROA } & $-0.028^{* * *}$ & $-0.005^{* * *}$ & $-0.008^{\star *}$ & $-0.003^{* * *}$ & $-0.005^{\star}$ \\
\hline & {$[-2.73]$} & {$[-3.11]$} & {$[-2.59]$} & {$[-3.01]$} & {$[-1.78]$} \\
\hline \multirow[t]{2}{*}{ Size } & -0.066 & -0.013 & $0.096^{*}$ & 0.024 & 0.053 \\
\hline & {$[-1.07]$} & {$[-1.19]$} & {$[1.86]$} & {$[1.10]$} & [1.16] \\
\hline \multirow[t]{2}{*}{ Tangibility } & 0.004 & 0.001 & 0.000 & 0.000 & 0.001 \\
\hline & {$[0.83]$} & {$[0.93]$} & {$[0.06]$} & [0.33] & [0.68] \\
\hline \multirow[t]{2}{*}{$\mathrm{RnD}$} & -0.012 & -0.002 & 0.006 & $0.002^{*}$ & 0.003 \\
\hline & {$[-0.81]$} & {$[-0.87]$} & {$[1.55]$} & [1.69] & {$[0.78]$} \\
\hline \multirow[t]{2}{*}{ Leverage } & $0.010^{* *}$ & $0.002^{* *}$ & $0.004^{* *}$ & 0.000 & $0.003^{*}$ \\
\hline & [2.05] & [2.07] & [2.11] & {$[-0.02]$} & {$[1.73]$} \\
\hline \multirow[t]{2}{*}{ InAge } & -0.004 & -0.004 & 0.225 & $0.128^{\star \star}$ & 0.272 \\
\hline & {$[-0.03]$} & {$[-0.16]$} & {$[0.97]$} & [2.14] & [1.34] \\
\hline \multirow[t]{2}{*}{ Block } & -0.003 & -0.001 & $-0.004^{\star \star \star}$ & $-0.001^{\star \star *}$ & $-0.003^{\star * *}$ \\
\hline & {$[-0.84]$} & {$[-0.96]$} & {$[-2.65]$} & {$[-3.52]$} & {$[-2.75]$} \\
\hline Firm effects & no & no & yes & yes & yes \\
\hline Industry effects & yes & yes & no & no & no \\
\hline Country effects & yes & yes & no & no & no \\
\hline Year effects & yes & yes & yes & yes & yes \\
\hline Observations & 1,201 & 1,201 & 1,201 & 1,201 & 1,201 \\
\hline Adj. $R^{\wedge} 2$ & n.a. & 0.124 & 0.142 & 0.101 & 0.080 \\
\hline
\end{tabular}

Notes: This table reports panel data regressions that re-examine the employment-performance sensitivity analysis from Table 5 on a propensity score matched sample for different dependent variables. Performance is proxied by ROA (in \%), as in Table 5. Specification I is a pooled logit regression, Specification II a pooled OLS regression, both include year-, industry-, and time effects. Specifications III-V are fixed effects OLS regressions with year-fixed effects. Matching uses Stata's psmatch2 calling a 1:2 nearest neighbor matching of BLER firms vs non-BLER firms with replacement based on the set of covariates for 2007 (our last pre-crisis year) as used in the determinants regression Table 4, Specification III.. For firm-fixed effects models, aggregate cem weights are used in the regression. The sample period is 2004-2010. All variables are described in detail in Table 1. Numbers in brackets are t-values robust to heteroscedasticity and residuals clustering at the firm level.

Significance levels: ${ }^{*} \mathrm{p}<0.10,{ }^{*} \mathrm{p}<0.05,{ }^{* * *} \mathrm{p}<0.01$. 
Table Appendix.2: Predicting employment reductions

\begin{tabular}{|c|c|c|c|}
\hline Dependent variable & $\Delta$ & $\Delta 5+$ Percent & $\Delta 10+$ Percent \\
\hline Method & OLS & Probit & Probit \\
\hline Sample & & BLER=0 & \\
\hline Specification & $\mathbf{I}$ & II & III \\
\hline \multirow[t]{2}{*}{ Size } & 0.006 & 0.058 & 0.063 \\
\hline & [0.90] & {$[0.86]$} & [0.84] \\
\hline \multirow[t]{2}{*}{ ROA } & $-0.001^{*}$ & $-0.014^{\star \star \star}$ & $-0.014^{\star \star \star}$ \\
\hline & {$[-1.86]$} & {$[-3.08]$} & {$[-2.91]$} \\
\hline \multirow[t]{2}{*}{ Tangibility } & -0.001 & -0.005 & -0.005 \\
\hline & {$[-1.44]$} & {$[-0.84]$} & {$[-0.88]$} \\
\hline \multirow[t]{2}{*}{$\mathrm{RnD}$} & 0.001 & 0.010 & 0.008 \\
\hline & [0.72] & [0.91] & {$[0.69]$} \\
\hline \multirow[t]{2}{*}{ Leverage } & 0.000 & 0.006 & 0.003 \\
\hline & {$[-0.21]$} & [1.11] & {$[0.57]$} \\
\hline \multirow[t]{2}{*}{ InAge } & -0.021 & -0.138 & -0.276 \\
\hline & {$[-1.46]$} & {$[-0.78]$} & {$[-1.56]$} \\
\hline \multirow[t]{2}{*}{ Block } & $0.001^{* *}$ & 0.002 & 0.007 \\
\hline & {$[2.05]$} & [0.52] & {$[1.46]$} \\
\hline Firm effects & no & no & no \\
\hline Industry effects & yes & yes & yes \\
\hline Country effects & yes & yes & yes \\
\hline Year effects & yes & yes & yes \\
\hline Observations & 276 & 266 & 262 \\
\hline Adj. $R^{\wedge} 2$ & 0.095 & & \\
\hline
\end{tabular}

Notes: This table reports pooled OLS and Probit regressions that explain the employment reduction of non-BLER firms during the crisis. The sample period is 2008-2009. All variables are described in detail in Table 1. Numbers in brackets are t-values robust to heteroscedasticity and residuals clustering at the firm level.

Significance levels: ${ }^{*} \mathrm{p}<0.10,{ }^{* *} \mathrm{p}<0.05, * * * \mathrm{p}<0.01$. 


\section{References}

Addison, J. T., and C. Schnabel. 2011. 'Worker Directors: A German Product that Did Not Export?' Industrial Relations 50(2):354-374.

Ai, C., and E. C. Norton. 2003. 'Interaction Terms in Logit and Probit Models.' Economics Letters 80(1):123-129.

Aidt, T. and Z. Tzannaos. 2002. Unions and collective bargaining: Economic effects in global environment. Washington, DC: World Bank.

Akerlof G. A., and J. L. Yellen. 1990. 'The Fair Wage-effort Hypothesis and Unemployment.' Quarterly Journal of Economics 105(2):255-283.

Andersen, S. K., Dølvik, J. E. and Ibsen, C. L. 2014. Nordic labour market models in open markets, European Trade Union Institute Report, Brussels: ETUID aisbl.

Aoki, M. 1984. The Cooperative Game Theory of the Firm. Oxford, UK: Oxford University Press.

CEEMET, 2012. Flexible forms of employment in the metal, engineering and technology-based industries, Brussels: CEEMET aisbl.

European Commission. 2009. 'Impact of the Current Economic and Financial Crisis on Potential Output.' EU Occasional Papers 49 (June).

Fauver, L., and M. E. Fuerst. 2006. 'Does Good Corporate Governance Include Employee Representation? Evidence from German Corporate Boards.' Journal of Financial Economics 82(3):673-710.

Frank, D. H. 2014. 'Governance Institutions and Adaptation Costs: Evidence from the Fall of the Berlin Wall.' Management Science 60(1):166-187.

Freeman, R. B., and E. P. Lazear. 1995. ‘An Economic Analysis of Works Councils.' In Works Councils, Consultation, Representation and Cooperation in Industrial Relations, edited by J. Rogers and W. Streeck, pp. 27 50. Chicago, IL: University of Chicago Press.

Gahan, P. G. 2002. '(What) do unions maximize? Evidence from survey data.' Cambridge Journal of Economics, 26:279-298. 
Garnero, A. 2018. 'What we do and what we don't know about worker representation on boards.' Harvard Business Review, 6(September 2018). Available at: https://hbr.org/2018/09/what-we-do-and-dont-know-aboutworker-representation-on-boards (Accessed: 11-December-2018).

Glassner, V., M. Keune, and P. Marginson. 2011. 'Collective Bargaining in a Time of Crisis: Development in the Private Sector in Europe.' Transfer 17(3):303-321.

Gorton, G., and F. Schmid. 2004. 'Capital, Labor, and the Firm: A Study of German Codetermination.' Journal of European Economic Association 2(5):863-905.

Gregoric, A., and T. Poulsen. 2018. 'The Power of [the] Non-Controlling Stake: Below-Parity Representation of Employees on Corporate Boards.' SSRN Working Paper.

Gross, D., and C. Acidi. 2010. 'The Crisis and the Real Economy.' Intereconomics 1:4-20.

Hansen, J. L. 2003. Nordic Company Law: The Regulation of Public Companies in Denmark, Finland, Iceland, Norway and Sweden: Copenhagen. Denmark: DØF Publishing.

Jackson, G. 2005. 'Employee Representation in the Board Compared: A Fuzzy Sets Analysis of Corporate Governance, Unionism and Political Institutions.' Industrielle Beziehungen, 12:1-28

Jones, D. 1987. 'The Productivity Effects of Worker Directors and Financial Participation by Employees in the Firm: The Case of British Retail Cooperatives.' Industrial and Labor Relations Review 41:79-92.

Kochan, T. A., and P. Osterman. 1994. The Mutual Gains Enterprise. Boston: Harvard Business School Press.

Lawson, N. P. 2011. 'Is Collective Bargaining Pareto Efficient? A Survey of the Literature.' Journal of Labor Research 32 (September):282-304.

Leontieff, W. 1946. 'The Pure Theory of Guaranteed Annual Wage Contract.' Journal of Political Economy 54(1):76-79.

Lins, K. V., P. Volpin, and H. F. Wagner. 2013. 'Does Family Control Matter? International Evidence from the 2008-2009 Financial Crisis.' Review of Financial Studies 26(10): 2583-2619.

McCain, R. A. 1980. ‘A Theory of Codetermination.’ Journal of Economics 40(1-2):65-90.

McDonald, I., and R. Solow. 1981. 'Wage Bargaining and Employment.' American Economic Review 71(5):896908. 
Matsa, D. A., and A. Miller. 2013. 'A Female Style in Corporate Leadership? Evidence from Quotas.' Applied Economics 5(3):136-169.

Mizrahi, S. 2002. 'Workers' Participation in Decision-Making Process and Firm Stability.' British Journal of Industrial Relations 40(4):0007-1080.

Strauss, G., and E. Rosenstein. 1970. 'Workers' Participation: A Critical View.' Industrial Relations: A Journal of Economy and Society 9(2):197-214.

Svalund, J., G. B. Casinowsky, J. E. Dølvik, K. Håkansson, A. Jarvensivu, H. Kervinen, R. J. Møberg, and T. Piirainen. 2013. 'Stress Testing for Nordic Models: Manufacturing Labour Adjustments during Crisis.’ European Journal of Industrial Relations 19(3):183-200.

Svejnar, J. 1981. 'Relative Wage Effects of Unions, Dictatorship, and Codetermination: Economic Evidence from Germany.' Review of Economics and Statistics 63:188-197.

Willman, P., Bryson, A., Gomez, R., and Kretschmer, T. (2014). 'Employee voice and the transaction cost economics project', in Wilkinson, A., Donaghey, J., Dundon, T., and Freeman, R. B. (eds.), Handbook of Research on Employee Voice, Edward Elgar: 52-66. 
${ }^{1}$ Accordingly, in developed countries we observe a renewed interest in employee participation on the board of directors. For example, recently the U.S. Senator Elizabeth Warren suggested that employees of large US firms should be allowed to send representatives to the boardroom. Similarly, during her campaigning, Theresa May, the current British Prime Minister, contemplated providing British workers such an option. See also Garnero (2018).

${ }^{2}$ With the term "cooperative" we refer to integrative solutions that should be preferable for both employers and employees, thereby either increasing the benefits of both or increasing the benefits of one party at no expense to the other. Such solutions might involve alternative measures of labor-cost savings in the interest of preserving employment during a crisis (McDonald and Solow, 1981; Aoki, 1984; Glassner et al., 2011; Svalund et al., 2013). Note that we use the terms cooperative and integrative interchangeably in this paper.

${ }^{3}$ With the term employers we refer to shareholders or to managers representing the shareholders.

${ }^{4}$ For a similar approach, see for example Lins et al. (2013).

${ }^{5}$ Although we do not fully spell out the theoretical model, our arguments and intuition borrow from the labor economics literature (for an overview, see for example Lawson, 2011). Also, note that we ignore taxes in our arguments. However, one might easily incorporate tax arguments without materially altering the conclusions.

${ }^{6}$ Aoki (1984) builds on the classical work of Leontieff (1946) and McDonald and Solow (1981) to explore the inefficiency of unilateral decision-making in the case of a negative demand shock.

${ }^{7}$ According to a reference reported by Svalund et al. (2013), when facing economic or production-related difficulties, the employers in Scandinavia are allowed to dismiss employees without incurring any other costs than the payment of salaries throughout the notice period.

${ }^{8}$ Denmark and Norway eased the existing arrangements for temporary absences and work-sharing schemes. In Sweden, the main actors in the manufacturing sector signed a path-breaking agreement for negotiated work- and burden-sharing that allowed for a reduction of working time at the company level to 80 percent without compensation; the companies could also decide to dismiss employees for a limited number of days with a corresponding lower pay. Reportedly, the manufacturing sector provided a reference for the other sectors, resulting in a number of workplace-level agreements that allowed unpaid, temporary furloughs in order to save jobs (Svalund et al., 2013).

${ }^{9}$ There are relatively minor differences in the weight of employee representation across the three Scandinavian countries. In Denmark, if represented on the board, workers hold at least half as many board seats as are held by shareholder representatives, but in any case not fewer than two. In Sweden, the employees elect two (three) board representatives in companies with at least 25 (1000) workers. In Norwegian firms employing at least 30 (50) workers, the employees elect one representative (one third of the board and no fewer than two). In firms with at least 200 employees, the directors are nominated through an assembly consisting of 12 members, of which one third are employee representatives who can in turn decide to elect one third of the board from among the employees.

${ }^{10}$ The main sources of directors' data were publicly available corporate websites and annual reports. When in doubt, we checked the information using other sources (internet) or contacting the companies directly.

${ }^{11}$ We define $\Delta 5+$ Percent as a forward-looking measure, i.e. from $\Delta 5+$ Percent $(\mathrm{t})$ measures the change in employment from end of year $t$ to end of year $t+1$, to account for the fact that the negotiation and implementation of layoff decisions requires some time.

12 The results of Table 3 also indicate that values of Labor intensity and Labor costs per Revenues at the end of 2010 are significantly related to implemented changes in the employment during 2006-2010 period (Delta Employees).

${ }^{13}$ Industry dummies are based on two-digit SIC codes with further aggregations of similar groups in cases of one or very few firm observations per group.

${ }^{14}$ The definition of industries here is compatible with the one used in Specifications (I) and (II). See footnote 13.

${ }^{15}$ Scandinavian firms have the so-called dual board system. This means that the board of directors is formally separated from the executive team, but one member of the team, generally the CEO, can be also a member of the board of directors, if decided so by firms' shareholders. Regardless of the CEO presence on board, the board of directors in Scandinavia plays a key role in firms' strategic decisions. For more, see Hansen (2003).

${ }^{16}$ In additional, untabulated tests, we also expand the sample period and estimate pooled probit and OLS regressions.

${ }^{17}$ Results of these robustness tests are not reported for the sake of space but available on demand.

18 The US National Bureau of Economic Research (NBER) places the Great Recession between December 2007 and June 2009. See http://www.nber.org/cycles.html (accessed November 25th, 2017). For European firms, we allocate the years 2008 and 2009 to this time period (see for instance Glassner et al., 2011).

${ }^{19}$ For a full description of the variables and their sources, see Table 1.

${ }^{20}$ The null hypothesis for the F-test is $\beta_{R O A}+\beta_{R O A * \text { Crisis }}+\beta_{R O A * B L E R}+\beta_{R O A * C r i s i s * B L E R}=0$. 
${ }^{21}$ For eyeball inspection, we illustrate in Appendix.Figure 1 in the appendix frequencies of the estimated propensity score over groups (treated firms, i.e. BLER firms, vs. untreated firms, i.e. Non-BLER firms) to document the common support.

${ }^{22}$ Except for union density, there are no large differences in the distribution of BLER across the subsamples defined by these firm characteristics. BLER is observed in 51.3\% of firms without family or other long-term owners and in $59 \%$ of the firms where such owners are in control. BLER is present in $40 \%$ of firms with moderate (low) union strength and in $60 \%$ of firms with high union strength. About $53 \%$ of firms with their headquarters outside the capital regions have employee directors on their boards, compared to $49 \%$ of firms in the capital regions.

${ }^{23}$ We run one more check here. Specifically, we divide the companies into those operating in industries with belowaverage union density and those operating in industries with above-average (high) union density, using the simple average sector-level union density values provided in Andersen et al. (2014) and assuming an equal distribution of firms between sectors. The effect of BLER is found to be stronger in the firms with below-average union density than in those with high union density. These results are somewhat expected, as the marginal utility of having an employee board representative is probably lower in industries with stronger unions, where sector-level agreements might have resulted in a wider adoption of cooperative solutions, even in the firms without employee representation on their corporate boards.

${ }^{24}$ Multiplying the coefficient, which is -60.5 , with $1 \%$, gives 0.605 . As the dependent variable is Relative change in labor costs per employee (in \%), this suggests that a one percent higher employment during crisis is compensated by a 0.6 percent decrease in labor costs per employee in the average BLER firm.

${ }^{25}$ In an unreported test, we also re-estimated Specification I by adding interaction terms between Block, Capital and Unionization, and ExcessEmployment. Our main results remained unaffected. 